\title{
RADIOCARBON DATING OF THE AMPHIPOLIS BRIDGE IN NORTHERN GREECE, MAINTAINED AND FUNCTIONED FOR 2500 YEARS
}

\begin{abstract}
$\mathrm{Y}_{\text {Maniatis }}{ }^{1,2} \cdot \mathrm{D}_{\text {Malamidou }}^{3} \cdot \mathrm{H}_{\text {Koukouli-Chryssanthaki }}^{2} \cdot \mathrm{Y} \mathrm{Facorellis}^{1}$
ABSTRACT. The remains of a wooden construction, recovered in the 1970s at the northwest sector of the walls of the ancient city of Amphipolis (northern Greece), have been recognized as foundation remains of a wooden bridge described by Thucydides in his description of the events that took place at Amphipolis in 424-422 BC, during the Peloponnesian War. Frequent repairs in the Roman, Byzantine, and even Ottoman periods are very probable. In the last $10 \mathrm{yr}$, conservation has been done to enhance this unique monument. This work involves systematic investigation with radiocarbon dating of all the verified or suspected phases of this wooden bridge. The dating results reveal the beginning of construction most probably in the Archaic period and confirm beyond a doubt that the major construction phase took place in Classical times. Successive phases, related to repairs rather than to major reconstructions, have been detected during the Hellenistic, Roman, Early Christian, and Byzantine periods as well as the Ottoman era. The combined archaeometric and archaeological evidence leads to the remarkable conclusion that this bridge was functioning for about $2500 \mathrm{yr}$.
\end{abstract}

\section{INTRODUCTION}

\section{Amphipolis: General Historical Context}

Amphipolis is located on the mouth of the Strymon River in eastern Macedonia, northern Greece (Figures 1 and 2). The ancient city was situated on the southwest foothills of Pangaeon Mountain. This mountain played a major role in the development of Amphipolis, providing timber from its dense forests and gold and silver from its mines. The Strymon River, surrounding the city to the north, west, and south, kept open the city's communications with the lower Strymon Valley, rich in agricultural products. The Strymonikos Gulf, comprising the southern border of the Amphipolis area, provided easy commercial and cultural access to the Greek cities of the Aegean Sea (Lazaridis 1972). In antiquity, the estuary of the Strymon River was located more to the east, in the area of the ancient Eion, the port of Amphipolis (Figure 1).

There is strong evidence of human habitation in several sites of the broader area already from the Neolithic (6th millennium BC). The prehistoric site nearest to Amphipolis is located on Hill 133 (Figures 1 and 2), $2 \mathrm{~km}$ northeast of the ancient city. At this site, surface finds and excavations have uncovered a Neolithic settlement and - probably after a hiatus during the Bronze Age - an Early Iron Age settlement (Lazaridis 1965; Vanterpool 1965), associated with a tumuli cemetery on the neighboring Kastas Hill (Lazaridis 1977a, 1978). The findings of the burial tumuli are dated between the 10th and 7th century BC (Koukouli-Chryssanthaki 1993).

The first Greeks to arrive in the Amphipolis area were Ionians. Argilos (Figure 1) is the earliest known Greek colony on the coastline of the Strymonikos Gulf, founded in the mid-7th century BC by colonists from the island of Andros (Bonias and Perreault 1996, 2000; Perreault and Bonias 1998). Literary and archaeological evidence speak to the relations of Parians or their colonists, the Thasians, with the local Thracian tribes in the lower Strymon Valley. Callimachus (fragment 24) refers to a conflict between the Parians and the Thracian tribe of Bisaltes. Inscriptions on stone (Lazaridis 1976; Bonias 2000) as well as on coins of the Thracian tribes of the Pangaeon area (Svoronos 1919:100-15; Babelon 1967:1071-5) are written in the Parian alphabet.

\footnotetext{
${ }^{1}$ Laboratory of Archaeometry, National Centre for Scientific Research “Demokritos," 15310 Aghia Paraskevi, Attiki, Greece. ${ }^{2}$ Corresponding author. Email: maniatis@ims.demokritos.gr.

${ }^{3} 18$ th Ephorate of Prehistorical and Classical Antiquities, 17 Erithrou Stavrou, 65110 Kavala, Greece.
} 


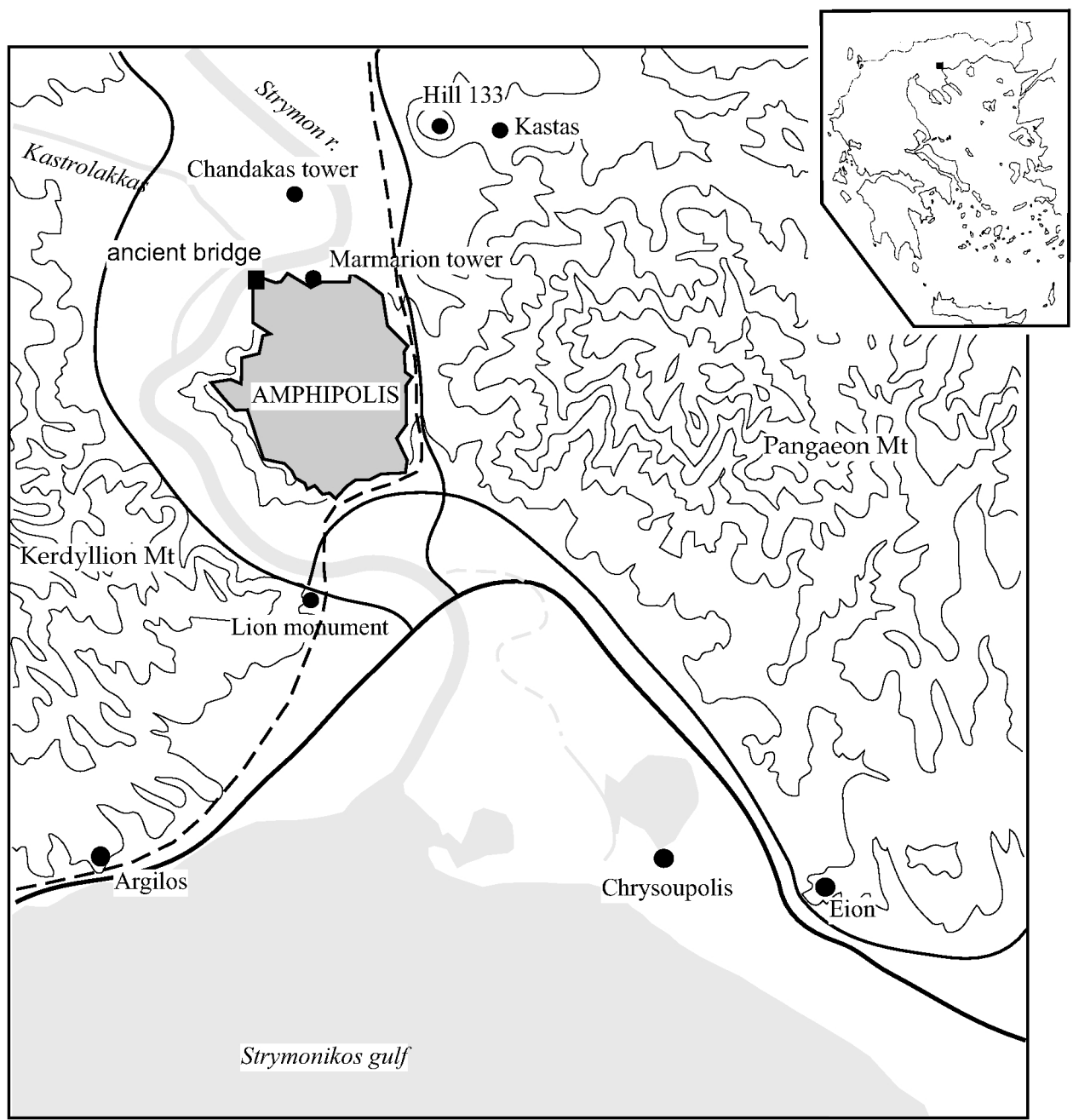

Figure 1 Map of Amphipolis and surrounding area. The dashed line indicates the Roman Via Egnatia.

At the end of the 6th and the beginning of the 5th century BC, important persons from Athens and Ionia were active in the area of Amphipolis: Peisistratos, exiled from Athens, became rich in the area of Pangaeon and succeeded to come back to Athens as a tyrant (Aristotle Athen. Const. XV; Herodotus I.64). During the occupation of the area by the Persians, Istiaeos, tyrant of Miletos, fortified Myrkinos (Herodotus V.23) and his successor, Aristagoras, lost his life in the early 5th century BC while trying to settle in the area of Amphipolis (Herodotus V.124; Thucydides IV.102)

The Early Iron Age settlement on Hill 133 was followed by a Late Archaic-Early Classical settlement, probably with a mixed population of Hedonians and Greeks. According to the archaeological evidence, this settlement seems to have been destroyed and abandoned around the mid-5th century BC. Identification of the settlement at Hill 133 with the Ennea Hodoi ("Nine Roads") mentioned in the literary sources was first proposed by Vanterpool (1965) and was widely accepted at first (Lazarides 1972; Pritchett 1981). This identification was recently rediscussed in the light of new evidence suggesting that the name Ennea Odoi is a toponym of an area, not just 1 settlement (Malami- 


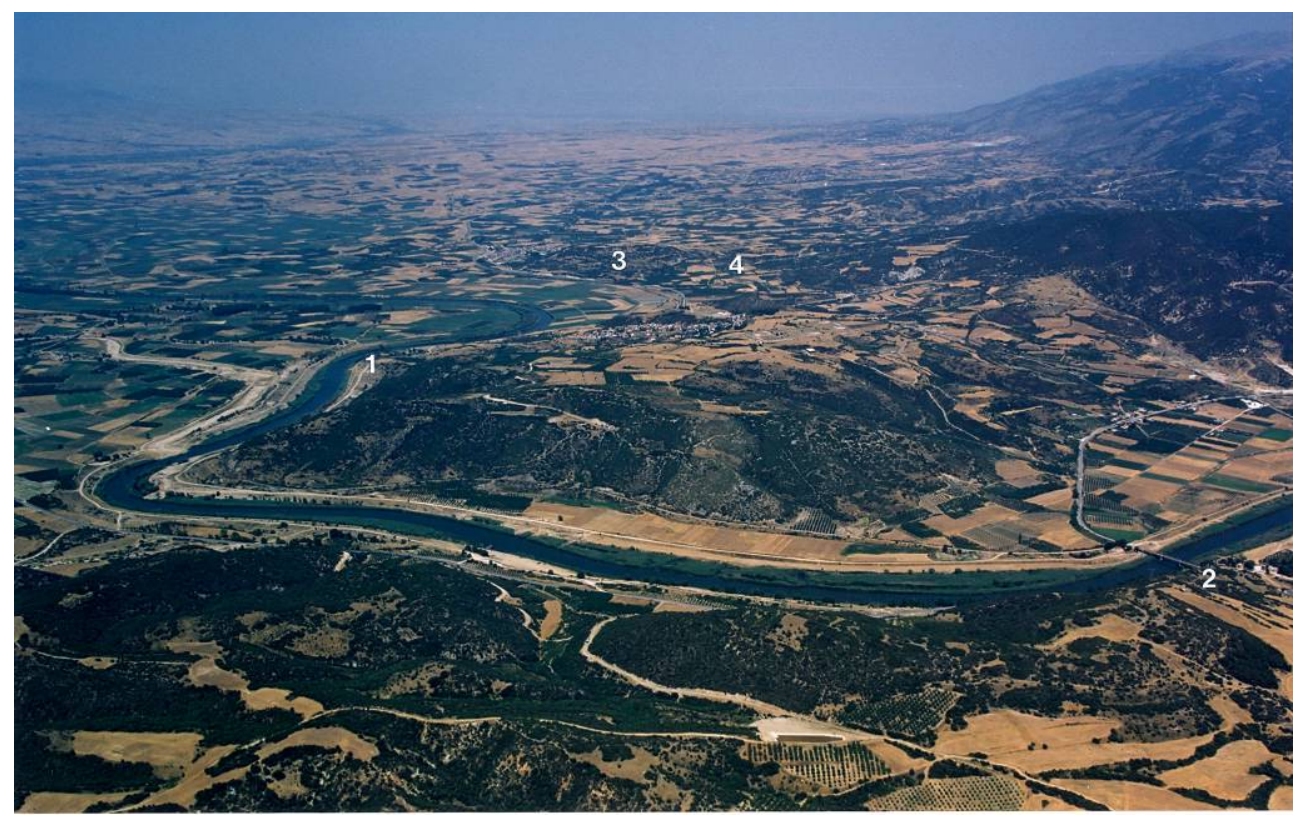

Figure 2 Aerial view of the Amphipolis area and the Strymon River: $1=$ location of wooden ancient bridge; $2=$ modern bridge and location of the Lion monument; $3=$ Hill 133; 4 = Kastas.

dou 2006, 2009). It has been suggested that Ennea Hodoi is rather an alteration of the name Hedonoi, a local Thracian tribe (Perdrizet 1922:40-2). However, the special sacrifices of 9 boys and 9 girls by Xerxes, when he crossed Ennea Hodoi with his army (Herodotus VII.114), show that at the beginning of the 5th century BC, this place name was widely accepted as a Greek name signifying "Nine Roads."

Eion (Figure 1), first settled by Parians or Thasians, was used by the Persians as a base of operations for their wars against Greece (Herodotus VII.25:107, 113). After the defeat of the Persians, the Athenians found the opportunity to occupy Eion in $476 \mathrm{BC}$, under the direction of General Kimon, and turned it into a military base and commercial port for themselves (Herodotus VII.107; Thucydides IV.102). Subsequently, the Athenians made continuous efforts to spread their influence on the mainland. In 465/4 BC, they sent 10,000 selected soldiers under the leadership of the Athenian generals Leagros and Sophanes, who managed to seize Ennea Odoi. However, when they attempted to expand their territory on the mainland, they were all killed at Draveskos (Thucydides I.100.3; IV.102.3).

The Athenians finally managed in $437 \mathrm{BC}$, during the reign of Pericles, to found Amphipolis under the leadership of General Hagnon (Thucydides IV.102.1). The newly founded Athenian colony was of considerable size and wealth. The city walls were impressive and elaborately built, running 7.5 $\mathrm{km}$ in length. In several areas of the peripheral walls, 6 gates have been recovered (Figure 3). Excavated houses, dated to the end of the 5th century BC, included Athenian and local pottery as well as works of sculpture and craftsmanship, reflecting the wealth and prosperity raised by the metropolitan city of Athens (Lazaridis 1972, 1977b).

Thirteen years later, however, in 424 BC, during the Peloponnesian War, General Brasidas of Sparta captured Amphipolis. Two years later, the Athenians tried to capture back the city. At the Battle of 


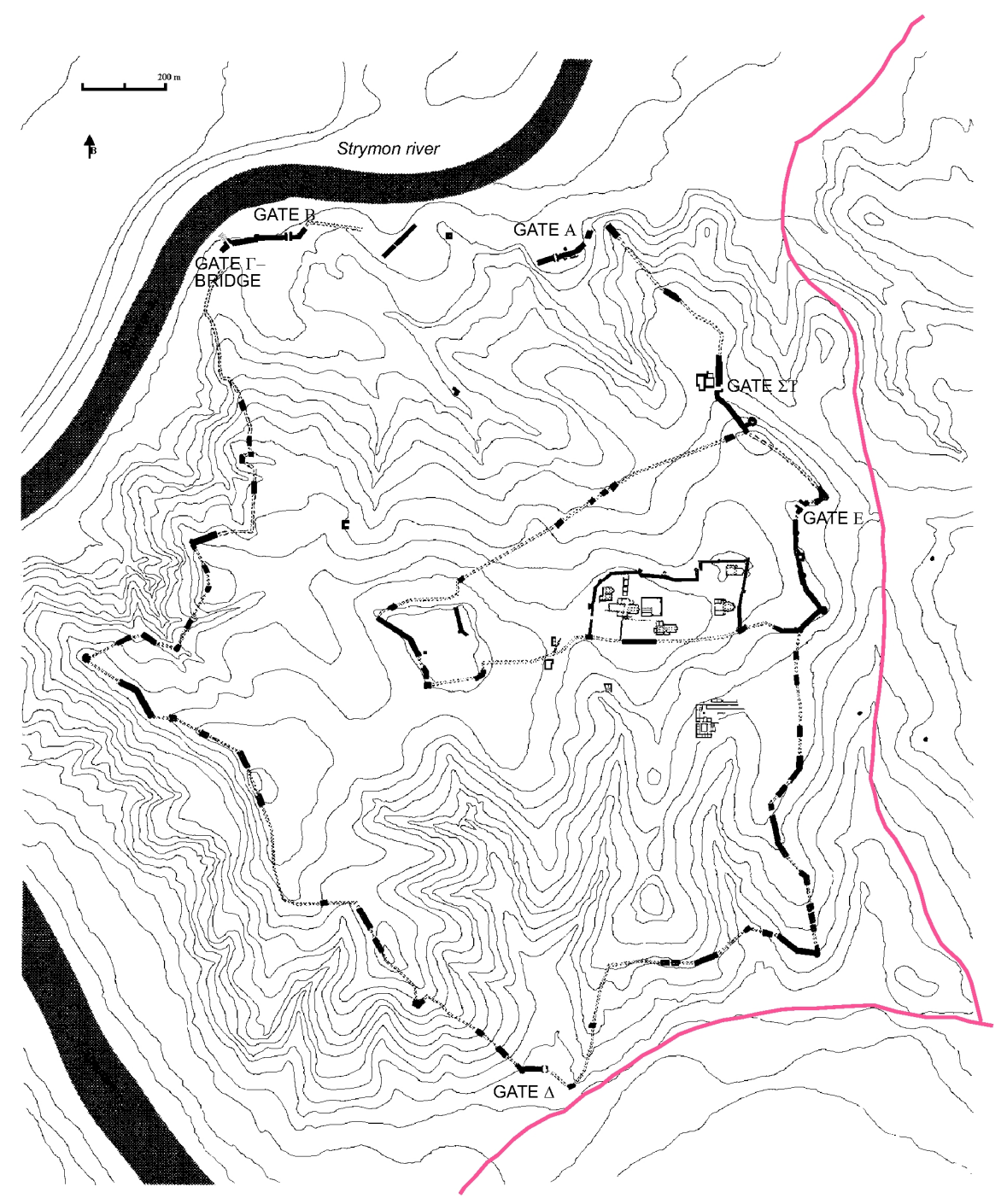

Figure 3 Map with the excavated monuments of ancient Amphipolis. Red lines show the modern roads.

Amphipolis (422 BC), the 2 generals, Kleon and Brasidas, were killed in front of the city walls and the Athenians finally retreated. General Brasidas was buried in the city receiving heroic funeral honors (Thucydides V.11.1). The city, being independent now, entered a new phase of prosperity and became open to all directions as a proper cosmopolitan center.

Another important moment in the history of Amphipolis was the occupation of the city by Philip II, in 358/7 BC, when he began the great expansion of the Macedonian kingdom. Macedonian political and military officials settled in the city (Papastavrou 1936:31-40; Hammond and Griffith 1979: 351-6). The Hellenistic era was a prosperous time for Amphipolis, as reflected in important private and public buildings recovered during archaeological excavations (Lazaridis 1997).

After the conquest of Macedonia by the Romans in 168 BC, Amphipolis became the capital of 1 of the 4 Macedonian provinces. In the Roman period, the city continued to be an important commercial 
center, since the Via Egnatia passed near it (Figure 1, dashed line) (Papastavrou 1936:148; Papazoglou 1988:392).

In the Early Christian period, Amphipolis became an important center of religious pilgrimage, as suggested by the monumental Christian basilicas decorated with mosaic floors and marble architectural decoration that were discovered during excavations in the acropolis of the city (Stikas 19621981; Bakirtzis 1988-1996; Zikos 1989).

The prosperity of the Early Christian period was followed by the collapse of the city, at the end of the 6th century BC, due to a plague that hit the Byzantine Empire in AD 541-543 (Bakirtzis 2000). The latter led to an important population decrease in all the Byzantine provinces and caused the destruction of many cities. Further decrease was probably caused by the invasions of the Avaroslavs (Konstantakopoulou 1984:202), who also reached Amphipolis in the centuries to follow (DoukataDemertzi and Commatas 1998).

Amphipolis survived during the 8th-9th centuries $\mathrm{AD}$, but in the 10th-11th centuries seems to have ceased to exist. A new city was founded under the name Chrysoupolis, on the mouth of the Strymon, not far from the site of ancient Eion (Figure 1) (Papazoglou 1953, 1988:388-9, 397; Duhn 1990). A small village took the place of Amphipolis, known later as Marmarion, which consisted basically of an intermediate station for travellers who were crossing the Strymon River through the "pass of Marmarion" (Kyriakidis 1939; Papangelos 1990).

From the 11th century onwards, the monasteries of Athos were holding large lands and metochia around ancient Amphipolis to which they owed much of their economic growth. In the middle of the 14th century AD, the towers of Marmarion and Chandakas were built on both sides of the river in order to oversee agricultural production (Papangelos 1990:331-51; Zikos 1998:312-7).

Chrysoupolis was a city-port on the road from Thessaloniki to Christoupolis (modern Kavala). From this port, boats sailed upstream the Strymon River to the lake of Achinos. Chrysoupolis remained a commercial center in the area of Amphipolis in the early Ottoman period. With the emergence of piracy in the Aegean, however, the city shifted from the coast to the mainland for security reasons (Duhn 1990). Chrysoupolis was succeeded by the smaller Ottoman fortress of Orphani, located 6 $\mathrm{km}$ to the east, $3 \mathrm{~km}$ away from the coast. The commercial and industrial shift, however, on the delta of the Strymon and the mouth of the river continued throughout the Ottoman period (Duhn 1981, 1990; Koukouli-Chryssanthaki et al. 1996).

Since the 18th century, a new village named Neochorion is mentioned in the area of Marmarion, located on the northern edges of ancient Amphipolis, which continued to be inhabited until the beginning of the 20th century (Leake 1835:191; Papangelos 1990; Zikos 1998).

\section{The Ancient Bridge: Excavation Data}

Literary texts mention bridges ( $\gamma \varepsilon \varphi v ́ \rho \alpha \varsigma$ ) (Herodotus VII.24.1, VII.114.1) or a bridge ( $\gamma \varepsilon \dot{\varepsilon} \varphi v \rho \alpha v$ ) (Thucydides IV.103.4) over the Strymon River, while the river itself is characterized by Euripides as "well-bridged" ( $\kappa \alpha \lambda \lambda l y \dot{\varphi} \varphi v \rho o \varsigma)$ (Rhesus, 349). An inscription found in the river, near the Lion monument, also refers to a bridge erected on the Strymon by the Legio X Fretensis, under the direction of L Tarius Rufus, pro-praetor in Macedonia during the reign of Roman Emperor Augustus (Keramopoulos 1932, 1934; Sarikakis 1971). Many scholars have discussed the location of Strymon's bridge(s) in an attempt to combine the literary and epigraphic evidence with the scanty archaeological finds (Leake 1835:191; Chryssochoos 1898; Pelekidis 1920; Keramopoulos 1934; Papastavrou 1936:148; Roger 1939; Broneer 1941; Gomme 1956; Pritchett 1965, 1971, 1981; Bakalakis 1970; 
Jones 1977; Lazaridis 1977a, 1997; Bougia 1996:193-200). They proposed different placements for the bridge to the west, south, and north of the ancient city of Amphipolis. The possibility for the existence of 2 bridges, one to the north and another to the south, has been also proposed (Pelekidis 1920; Papastavrou 1936:148; Roger 1939; Pritchett 1981).

Excavations conducted by D Lazaridis provided the first firm archaeological evidence on the existence of a bridge on the Strymon in Classical times (Lazaridis 1959, 1960, 1964, 1965, 1977a) (Figures 4 and 5). Excavation followed public works by the Prefecture of Serres in 1970 to widen and deepen the riverbed. During the excavation, the remains of a wooden construction were uncovered at the northwest sector of the ancient city. ${ }^{4}$ These remains were identified by the excavator as the end of a wooden bridge on the eastern bank of the river (Lazaridis 1977a, 1978, 1997:33-7). Conversely, the limited research that took place across the river did not provide any clear evidence of the other parts of this bridge in the river and on its opposite bank. Future research may supply some more evidence on the extension of the bridge, unless the remains have been damaged during extensive modern work on the drainage of Achinos Lake and the new shift of the Strymon riverbed by the MonksUlen Company in 1929-1932. In any case, this discovery is unique for Greece and rare for the ancient world (Bougia 1996). The wooden posts were preserved due to the wet environment near the permanent flow of the Strymon River.

Two gates, B and $\Gamma$ (Figure 3), in the city walls are near the location of the bridge. The bridge is connected with gate $\Gamma$, which belongs to a type of gate with 2 rectangular courtyards placed inside and outside respectively from the opening of the wall (Figure 4), quite similar to the form of the Classical gate $\mathrm{A}$ of the northern wall.

Gate $\Gamma$ stands $42.30 \mathrm{~m}$ from the present riverbank. Hundreds of posts, round or square in cross-section, wedged vertically on the sandy ground of the ancient bank or the bed of the river, were discovered along an area of $10 \mathrm{~m}$ in width, between the gate and the river. They were all covered with deposits of $4-5 \mathrm{~m}$ in thickness. The diameters of the posts in their current condition vary between 7 to $29 \mathrm{~cm}$, while their height ranges between 1.5 to $1.6 \mathrm{~m}$ (Figure 6). There are also several horizontal beams with the longest surviving one measuring $4.5 \mathrm{~m}$. The lower ends of the posts were cut into shaped edges (Figure 7), which in some cases have been placed on iron-pointed heads. Many such iron heads have been recovered from the bridge deposits as well as fragments of nails together with lead clamps. Iron tools collected in the deposits, such as axes, picks, and knifes, were apparently used for working the timber needed for building this wooden construction.

The excavator distinguished 2 groups of posts: a) posts with large dimensions placed at deep levels; and b) posts placed higher, which often have smaller diameters and seem to have been later in date. A layer of sand, pebbles, and stones exists between the 2 levels, probably deposited from the regular flow or the occasional overflow of the river.

The posts of the lowest layer give a better picture of their original pattern. Most of them are placed in small groups of 4 or 3 in order to strengthen the foundation of the bridge. They thus form 12 rows, almost parallel, measuring $6 \mathrm{~m}$ in width, which was possibly the width of the Classical bridge. The posts of the deepest layer, about 100 in number ( 77 outside and 24 inside the gate $\Gamma$ ) have been dated, according to the archaeological deposits, to the 5 th century BC. The posts of the higher layers have been dated to the Roman and Byzantine periods.

${ }^{4}$ To date, only preliminary reports on these excavations are available (see References, Lazaridis). 


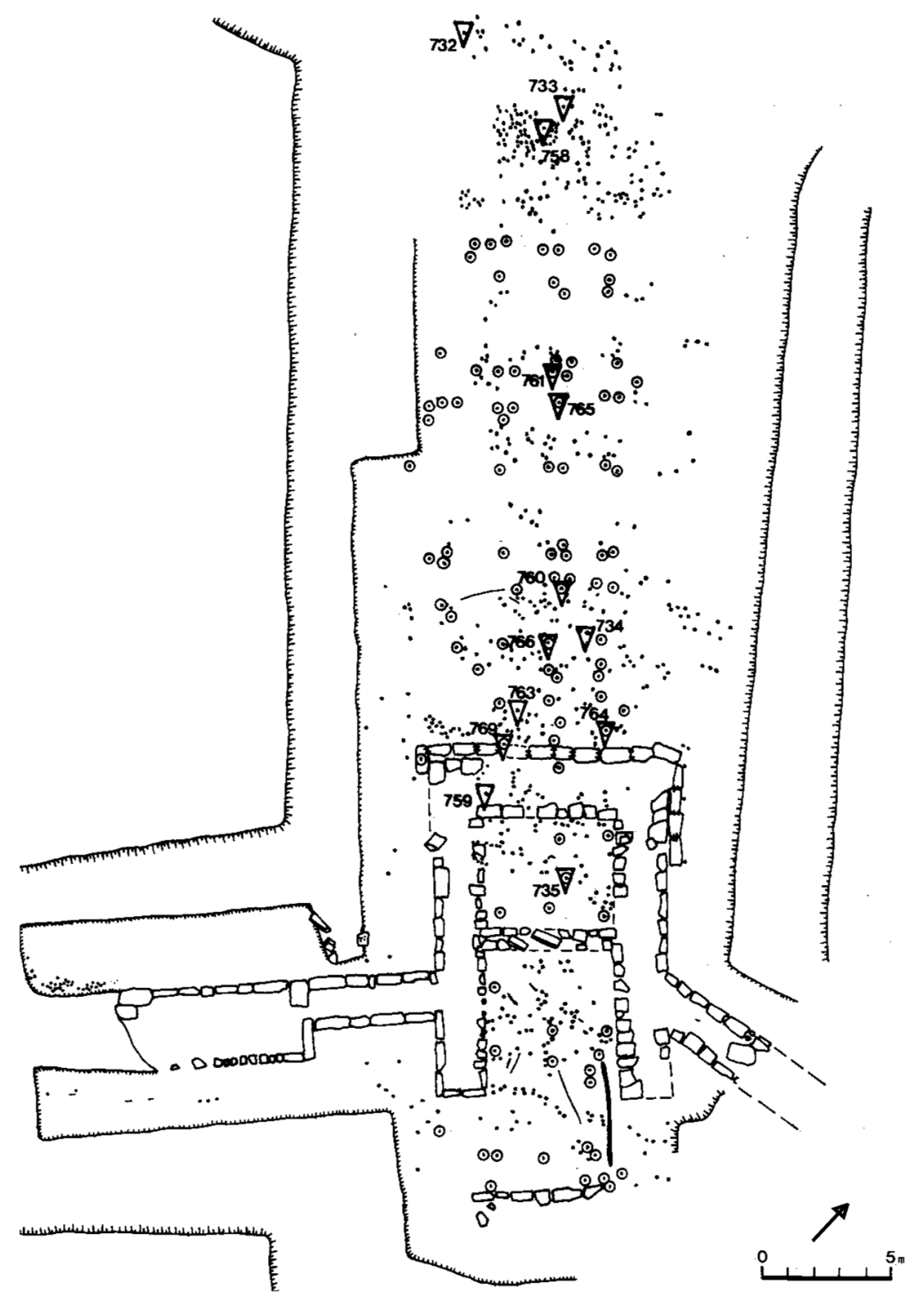

Figure 4 Plan of gate $\Gamma$ and excavated part of the bridge (wooden posts). Posts assigned to the Classical phase are indicated with circles. Sampled posts are indicated with triangles and labeled with the laboratory sample code numbers.

The ground around and inside gate $\Gamma$, as well as the zones inside and outside the wall, are, on the level of the foundation, strengthened further with a large number of wooden posts. This special construction aimed to strengthen the wall in case of a river overflow and also to stabilize the sandy ground of the riverbed. According to Lazaridis, some of the thick piles found inside gate $\Gamma$ and across the defensive walls might have been part of a pile construction, referred to by Thucydides as

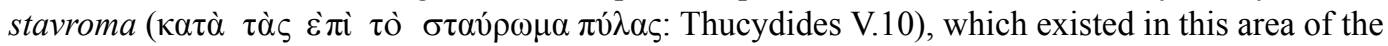
northern walls near the river. In addition to the wooden posts, one $\Pi$-shaped wall was built on the level of the gate, with big stone building blocks connected with double П-shaped clamps, probably for protecting the outside courtyard of the gate. 


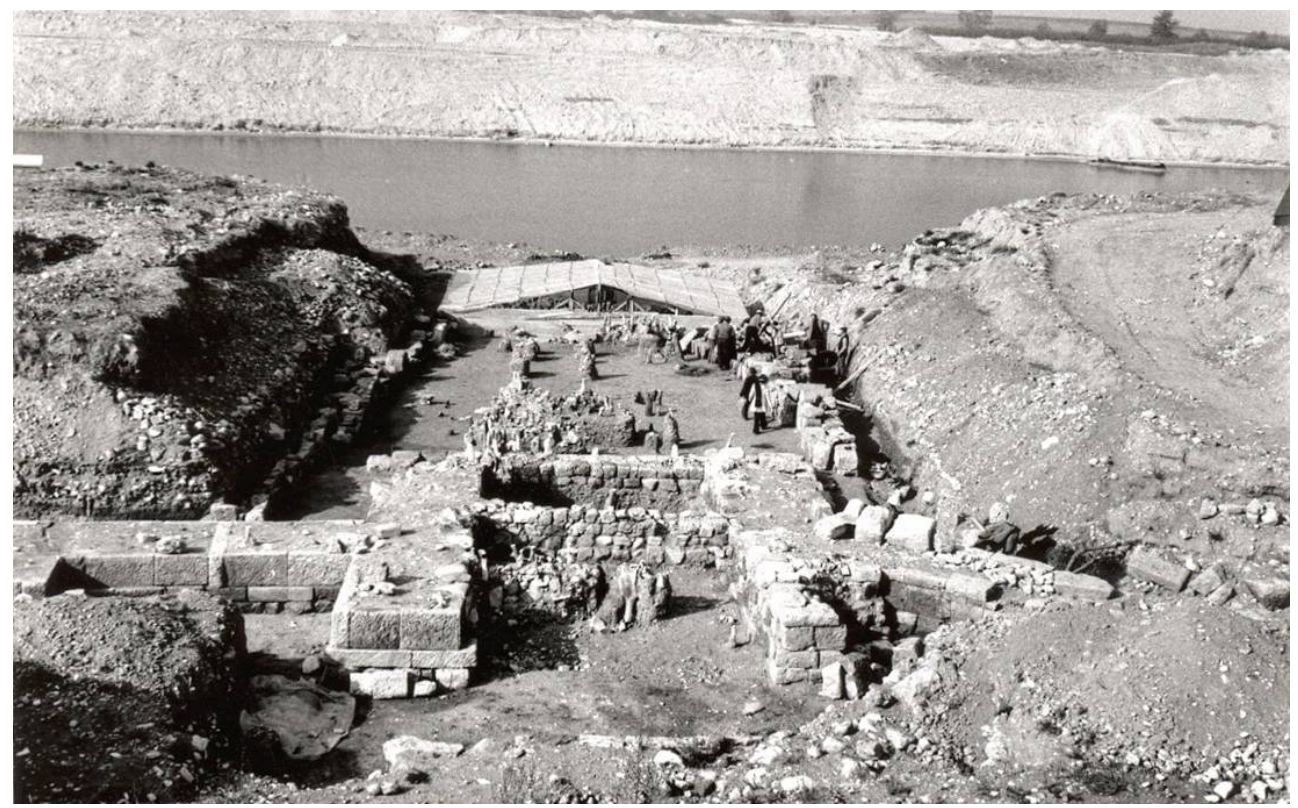

Figure 5 The ancient bridge during excavation, viewed from the south, showing part of the city walls and gate $\Gamma$ connected with the bridge.

Lazaridis' interpretation that these piles are the remains of an ancient wooden bridge, which was succeeded by a Roman bridge and later repeatedly repaired in the Byzantine or even Ottoman period, has been accepted as very probable (Pritchett 1981; Bougia 1996). It was further corroborated by references in the manuscripts of the Mount Athos monasteries (Papangelos 1990) and the reports of travellers (Belon 1553:55; Leake 1835:191). At the same location, Chryssochoos (1898) and, later, Pelekidis (1920) saw the remains of a wooden bridge in the river.

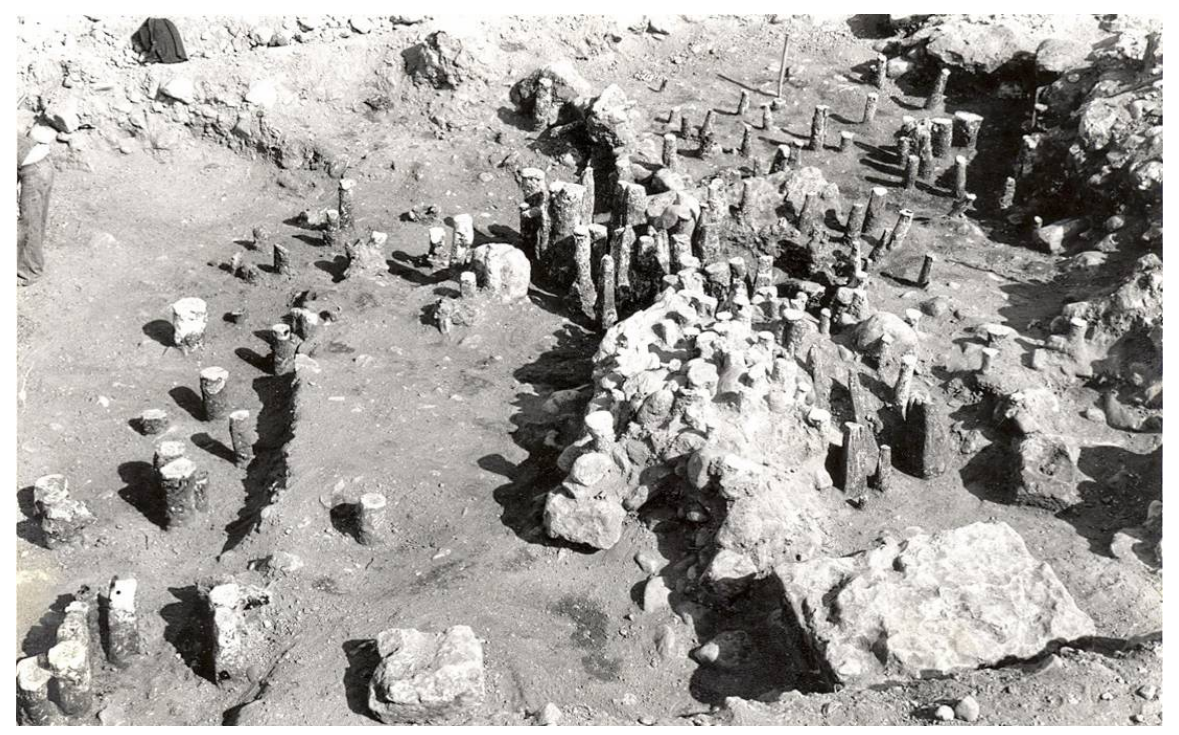

Figure 6 Northern part of the bridge, viewed from the west, showing wooden posts and plaster casts of posts. 


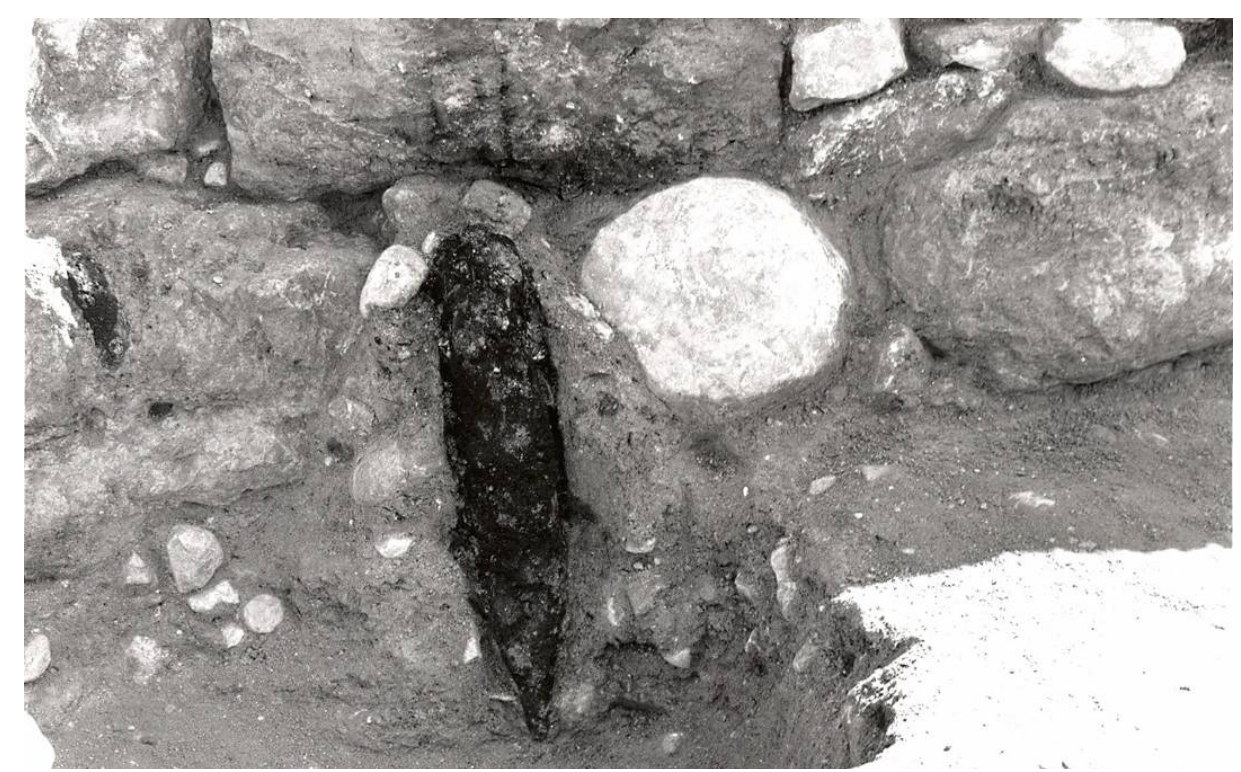

Figure 7 Details of the remaining lower part of a wooden post in situ, shaped into a pointed end.

In the last $5 \mathrm{yr}$, conservation has taken place, organized by the 18th Ephorate of Prehistoric and Classical Antiquities, to enhance this unique monument. During these works, a more accurate dating of the various phases of building and use of the bridge seemed necessary; this task could be completed with the help of radiocarbon dating.

The aim of this study is therefore to systematically investigate with the use of ${ }^{14} \mathrm{C}$ dating all the verified or suspected phases of this wooden construction and to obtain time series for both the intra- and interphase chronological sequences. In this way, we will be able to define the different periods of use on an absolute timescale. At the same time, the duration of each phase and subphase can be further clarified. By combining these ${ }^{14} \mathrm{C}$ dates with the known literary and archaeological evidence, the history and importance involved of the bridge can be revealed and further appreciated.

\section{SAMPLES AND EXPERIMENTAL TECHNIQUES}

Seventeen samples from the remains of wooden posts from the bridge were obtained (Figure 4). The goal was to collect as many samples as possible from archaeologically recognized or suspected phases of the bridge. In this respect, 8 posts were selected from the early layers, which were archaeologically dated to the 5 th century $\mathrm{BC}$ by the excavator, along with 5 posts from the later layers, dated to the Roman and Byzantine periods. Finally, 4 posts, which were removed from the site during the excavation of the surface layers and originated probably from the later chronological phases of the bridge, were added to the set of samples.

The posts sampled were not very wide in diameter, around $10-15 \mathrm{~cm}$, and the number of tree rings observable was no more than 20 , making any plans for wiggle-matching unavailable and reducing anxieties for serious age shifts due to old-wood effects. However, in order to further diminish any effects of time variation between the inner and outer parts of the trees used as posts, only the outermost few rings from every post were sampled, which represent as close as possible the felling date for each tree, assuming this is very close to the date of usage. This is a valid assumption since build- 
ing of a bridge is a major construction that requires cutting trees for this purpose and not the possible reuse of old house posts.

Samples were dated at the Laboratory of Archaeometry-Radiocarbon Unit, NCSR "Demokritos" (code: DEM) using the gas $\left(\mathrm{CO}_{2}\right)$ proportional counting technique. The wood samples were prepared as follows: after grinding to small chips, the samples are placed in a $4 \%$ solution of $\mathrm{NaOH}$ at $80{ }^{\circ} \mathrm{C}$, stirred well, and left in the water bath overnight. They were then transferred to an acid solution of $4 \% \mathrm{HCl}$ at $80^{\circ} \mathrm{C}$ where they stay for more than an hour and continuously stirred. The samples were then neutralized with hot $\left(100^{\circ} \mathrm{C}\right)$ deionized water. The whole cycle was repeated several times, until the water over the sample was clear. When the pretreatment was finished, the samples were dried in an oven at $100{ }^{\circ} \mathrm{C}$.

The dry wood samples are then combusted using a de Vries-type continuous combustion system (de Vries and Barendsen 1953; Münnich 1957) and converted to $\mathrm{CO}_{2}$. All the other oxides are removed by reaction of the gas with $\mathrm{KMnO}_{4}$ and the $\mathrm{CO}_{2}$ is then precipitated to calcium carbonate in a $\mathrm{CaCl}_{2} /$ $\mathrm{NH}_{4}$ solution. Consequently, the sample is turned again into $\mathrm{CO}_{2}$ by treatment with $\mathrm{HCl}$ acid. In the final purification step, impurities of the gas and particularly the radioactive radon gas are removed by passing the sample through a column filled with active charcoal kept at $0{ }^{\circ} \mathrm{C}$ (Kromer and Münnich 1992). The mass of every sample is adjusted to a fixed amount $(8.5 \mathrm{~g})$ and then measured in the counters.

The measuring system consists of 8 cylindrical copper gas proportional counters, 4 with a capacity of $4 \mathrm{~L}$ and 4 with $3 \mathrm{~L}$. The counters are surrounded by continuous-flow $\left(\mathrm{Ar}+10 \% \mathrm{CH}_{4}\right)$ guard counters, which monitor all incoming environmental radiation and separate it electronically from the actual sample counts by an anticoincidence system (Schoch et al. 1980). The samples are alternated every few days between the different counters and measured repeatedly, increasing in this way the accuracy and reliability of the results.

\section{RESULTS AND DISCUSSION}

The summary of the dating results is shown in Table 1 . The ${ }^{14} \mathrm{C}$ dates (BP) are listed by age from younger to older. Due to technical reasons, measurement of $\delta^{13} \mathrm{C}$ for the isotopic fractionation was not possible at the time of dating of these samples. For this reason, we used $\delta^{13} \mathrm{C}=-25.00 \%$, suggested as the value for non-fossil wood $(-25.00 \pm 2 \%$ ) (Polach 1976; Stuiver and Polach 1977) and from our own experience with measurements of wood samples all over Greece whose $\delta^{13} \mathrm{C}$ values range between $23-27 \%$. In order to accommodate for this possible variation in the $\delta^{13} \mathrm{C}$ value of the wood samples, we increased the final quoted error from the calculated $\pm 20 \mathrm{yr}$ to $\pm 38 \mathrm{yr}$, which is the combined uncertainty of \pm 20 and \pm 32 yr, the latter corresponding to the published value (Polach 1976; Stuiver and Polach 1977) and observed in our lab's measurements, $\pm 2 \%$ variance in the $\delta^{13} \mathrm{C}$ values in wood samples. Calibration of the ages was performed using CALIB v 5.0 (Stuiver and Reimer 1993) with the IntCal04 data set (Reimer et al. 2004). Uncertainty ranges of the calibrated dates corresponding to 1 and 2 standard deviations (probability $68.3 \%$ and $95.4 \%$, respectively) are given in Table 1. The calibrated ages for $2 \sigma$ are plotted in Figure 8. As there is no specific archaeological information for the chronological sequence of the individual samples but only gross characterization of groups of samples like "earlier phases," "later phases" and "surface layers," we have plotted the samples according to ${ }^{14} \mathrm{C}$ age, thus missing the chance for sequential analysis or Bayesian statistics. Within this broader sense of groupings, the dating results agree quite well (Table 1), apart from 1 sample. This sample (DEM-733) is thought to come from the later phases; however, it dates amongst the samples with the oldest ages (Table 1). 
Table 1 Summary of ${ }^{14} \mathrm{C}$ dating results for the Amphipolis bridge samples. The dates were calibrated using CALIB 5.0 (Stuiver and Reimer 1993).

\begin{tabular}{|c|c|c|c|c|c|}
\hline Lab code nr & Post nr & $\begin{array}{l}\text { Archaeological } \\
\text { information }\end{array}$ & $\begin{array}{l}{ }^{14} \mathrm{C} \text { age } \\
\text { (BP) }\end{array}$ & Calibrated age & Probability \\
\hline DEM-978 & 1 & $\begin{array}{l}\text { Surface layers } \\
\text { (Byzantine?) }\end{array}$ & $361 \pm 38$ & $\begin{array}{l}1460-1630 \mathrm{AD} \\
1450-1640 \mathrm{AD}\end{array}$ & $\begin{array}{l}(68.3 \%) \\
(95.4 \%)\end{array}$ \\
\hline DEM-763 & $203 \Gamma$ & $\begin{array}{l}\text { Later phases } \\
\text { (later than 5th c.) }\end{array}$ & $1453 \pm 38$ & $\begin{array}{l}\text { 580-645 AD } \\
545-655 \mathrm{AD}\end{array}$ & $\begin{array}{l}(68.3 \%) \\
(95.4 \%)\end{array}$ \\
\hline DEM-759 & A & $\begin{array}{l}\text { Later phases } \\
\text { (later than } 5 \text { th c.) }\end{array}$ & $1482 \pm 38$ & $\begin{array}{l}\text { 545-620 AD } \\
440-650 \mathrm{AD}\end{array}$ & $\begin{array}{l}(68.3 \%) \\
(95.4 \%)\end{array}$ \\
\hline DEM-734 & $\Delta$ & $\begin{array}{l}\text { Later phases } \\
\text { (later than } 5 \text { th c.) }\end{array}$ & $1562 \pm 38$ & $\begin{array}{l}430-545 \mathrm{AD} \\
415-580 \mathrm{AD}\end{array}$ & $\begin{array}{l}(68.3 \%) \\
(95.4 \%)\end{array}$ \\
\hline DEM-979 & 20 & $\begin{array}{l}\text { Surface layers } \\
\text { (Byzantine?) }\end{array}$ & $1595 \pm 38$ & $\begin{array}{l}420-535 \mathrm{AD} \\
390-555 \mathrm{AD}\end{array}$ & $\begin{array}{l}(68.3 \%) \\
(95.4 \%)\end{array}$ \\
\hline DEM-981 & 136 & $\begin{array}{l}\text { Surface layers } \\
\text { (Byzantine?) }\end{array}$ & $1604 \pm 38$ & $\begin{array}{l}\text { 410-535 AD } \\
355-555 \mathrm{AD}\end{array}$ & $\begin{array}{l}(68.3 \%) \\
(95.4 \%)\end{array}$ \\
\hline \multicolumn{3}{|c|}{ Average of DEM-734, -979, -981 } & $1587 \pm 22$ & $\begin{array}{l}425-535 A D \\
420-540 A D\end{array}$ & $\begin{array}{l}(68.3 \%) \\
(95.4 \%)\end{array}$ \\
\hline DEM-980 & 114 & $\begin{array}{l}\text { Surface layers } \\
\text { (Byzantine?) }\end{array}$ & $1751 \pm 38$ & $\begin{array}{l}235-340 \mathrm{AD} \\
140-400 \mathrm{AD}\end{array}$ & $\begin{array}{l}(68.3 \%) \\
(95.4 \%)\end{array}$ \\
\hline DEM-758 & 384 & $\begin{array}{l}\text { Later phases } \\
\text { (later than 5th c.?) }\end{array}$ & $2203 \pm 38$ & $\begin{array}{l}355-205 \mathrm{BC} \\
380-180 \mathrm{BC}\end{array}$ & $\begin{array}{l}(68.3 \%) \\
(95.4 \%)\end{array}$ \\
\hline DEM-764 & $17 \alpha$ & $\begin{array}{l}\text { Earlier phases } \\
\text { (5th c.?) }\end{array}$ & $2367 \pm 38$ & $\begin{array}{l}510-390 \mathrm{BC} \\
730-380 \mathrm{BC}\end{array}$ & $\begin{array}{l}(68.3 \%) \\
(95.4 \%)\end{array}$ \\
\hline DEM-760 & 35 & $\begin{array}{l}\text { Earlier phases } \\
\text { (5th c.?) }\end{array}$ & $2382 \pm 38$ & $\begin{array}{l}510-395 \mathrm{BC} \\
735-385 \mathrm{BC}\end{array}$ & $\begin{array}{l}(68.3 \%) \\
(95.4 \%)\end{array}$ \\
\hline DEM-765 & 61 & $\begin{array}{l}\text { Earlier phases } \\
(5 \text { th c.?) }\end{array}$ & $2385 \pm 38$ & $\begin{array}{l}510-395 \mathrm{BC} \\
740-385 \mathrm{BC}\end{array}$ & $\begin{array}{l}(68.3 \%) \\
(95.4 \%)\end{array}$ \\
\hline DEM-769 & 17 & $\begin{array}{l}\text { Earlier phases } \\
\text { (5th c.?) }\end{array}$ & $2389 \pm 38$ & $\begin{array}{l}515-400 \mathrm{BC} \\
745-390 \mathrm{BC}\end{array}$ & $\begin{array}{l}(68.3 \%) \\
(95.4 \%)\end{array}$ \\
\hline DEM-766 & 30 & $\begin{array}{l}\text { Earlier phases } \\
\text { (5th c.?) }\end{array}$ & $2391 \pm 38$ & $\begin{array}{l}515-400 \mathrm{BC} \\
745-390 \mathrm{BC}\end{array}$ & $\begin{array}{l}(68.3 \%) \\
(95.4 \%)\end{array}$ \\
\hline DEM-732 & 076 & $\begin{array}{l}\text { Earlier phases } \\
\text { (5th c.?) }\end{array}$ & $2408 \pm 38$ & $\begin{array}{l}540-400 \mathrm{BC} \\
750-395 \mathrm{BC}\end{array}$ & $\begin{array}{l}(68.3 \%) \\
(95.4 \%)\end{array}$ \\
\hline Average of $D$ & $4-764,-760,-7$ & $65,-769,-766,-732$ & $2387 \pm 16$ & $\begin{array}{l}505-400 B C \\
515-400 B C\end{array}$ & $\begin{array}{l}(68.3 \%) \\
(95.4 \%)\end{array}$ \\
\hline DEM-735 & 11 & $\begin{array}{l}\text { Earlier phases } \\
\text { (5th c.?) }\end{array}$ & $2445 \pm 38$ & $\begin{array}{l}740-410 \mathrm{BC} \\
755-405 \mathrm{BC}\end{array}$ & $\begin{array}{l}(68.3 \%) \\
(95.4 \%)\end{array}$ \\
\hline DEM-733 & 374 or $314 ?$ & $\begin{array}{l}\text { Later phases? } \\
\text { (later than 5th c.?) }\end{array}$ & $2448 \pm 38$ & $\begin{array}{l}745-410 \mathrm{BC} \\
755-405 \mathrm{BC}\end{array}$ & $\begin{array}{l}(68.3 \%) \\
(95.4 \%)\end{array}$ \\
\hline DEM-761 & 73 & $\begin{array}{l}\text { Earlier phases } \\
\text { (5th c.?) }\end{array}$ & $2453 \pm 38$ & $\begin{array}{l}750-415 \text { BC } \\
760-410 \text { BC }\end{array}$ & $\begin{array}{l}(68.3 \%) \\
(95.4 \%)\end{array}$ \\
\hline Average of 1 & M-735, -733, & & $2449 \pm 22$ & $\begin{array}{l}740-415 B C \\
755-410 B C\end{array}$ & $\begin{array}{l}(68.3 \%) \\
(95.4 \%)\end{array}$ \\
\hline
\end{tabular}

From Table 1 and Figure 8, using the 2- $\sigma$ ages, it can be seen that the wooden post dates define several periods, which should correspond to the different phases of construction, reconstruction, and repair of the bridge. The dates of these periods, represented by at least 1 sample, are approximately: 
- Period I: 760-380 BC;

- Period II: 380-180 BC;

- Period III: AD 140-400;

- Period IV: AD 400-580;

- Period V: AD 440-655;

- Period VI: AD 1450-1650.

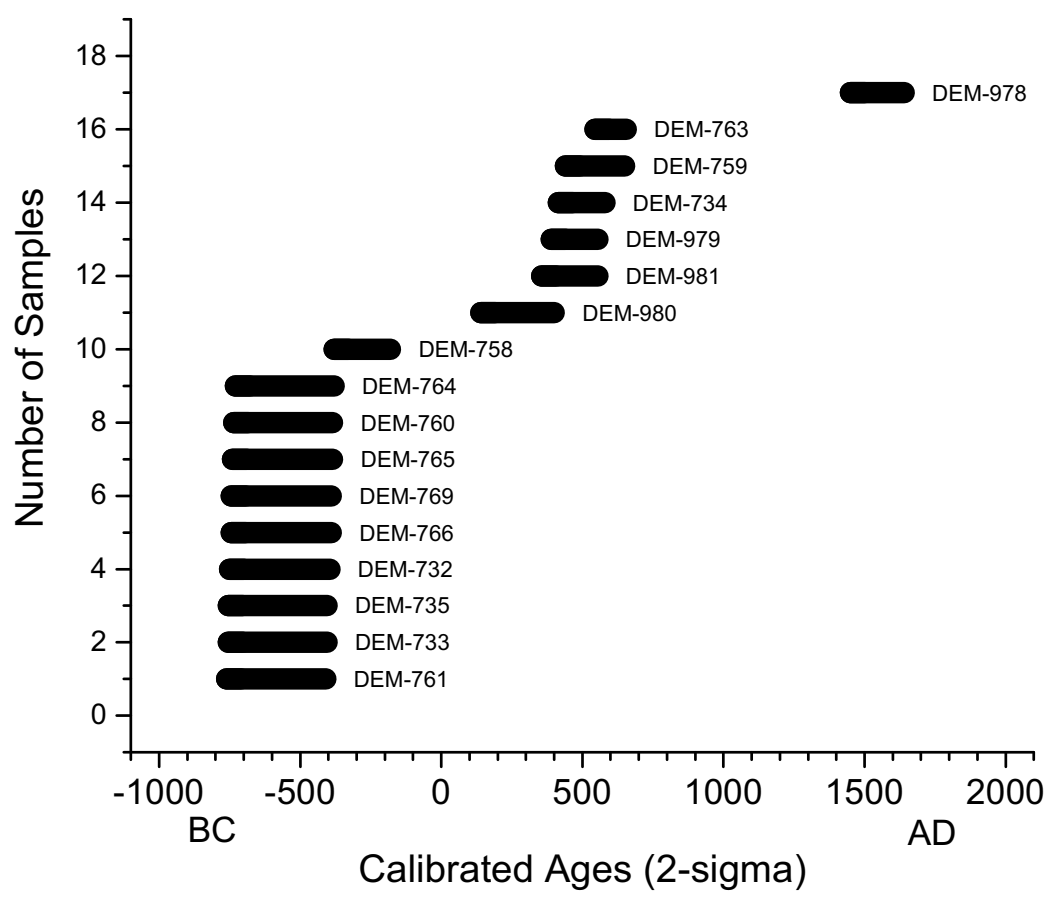

Figure 8 Calibrated dates $(2 \sigma)$ for the Amphipolis bridge wooden post samples. The samples are plotted according to ${ }^{14} \mathrm{C}$ age.

\section{Period I: $\mathbf{7 6 0 - 3 8 0 ~ B C}$}

The earliest period is defined by a group of 9 samples; 8 of them (DEM-761, -735, -732, -766, -769, $-765,-760,-764)$ coming from the earliest (deepest) construction layers of the bridge and 1 (DEM733) was initially believed to come from the later layers according to the excavators. This group exhibits an overall calibrated age span of 760-400 BC (2 $\sigma)$ (Table 1, Figure 8), which is particularly enlarged due to calibration curve anomalies. The ${ }^{14} \mathrm{C}$ dates fall in the difficult part of the calibration curve where a well-known long plateau exists spanning the period from about 760 to $400 \mathrm{BC}$ (Reimer et al. 2004). This age range unfortunately covers a lot of different and important cultural phases in the history of Greece, namely the Geometric period (800-700 BC), Archaic period (700-480 BC), and Classical period (480-323 BC) (Pedley Griffiths 1998). For this reason, it is a challenge to further interpret the ${ }^{14} \mathrm{C}$ dates in an attempt to explore the possibility of better anchoring the construction and use of the bridge within one or more of the above cultural periods.

Figure 9 shows the probability distributions of these 9 samples using the program OxCal 3.10 (Bronk Ramsey 1995, 2001). Examination of this plot and Table 1 reveals that the highest probabilities for 6 of these samples (DEM-732, -766, -769, -765, -760, -764) accumulate in the lower end of the plateau, specifically between $510-380$ BC (Table 1). The 1- $\sigma$ ages for these samples are all with 
$100 \%$ probability within this lower age range. Even for sample DEM-732, with the highest ${ }^{14} \mathrm{C}$ age among these samples (2408 $\pm 38 \mathrm{BP})$, the $1-\sigma$ calibrated age range is $100 \%$ within $540-400 \mathrm{BC}$. Furthermore, the calibrated 2- $\sigma$ ages for these samples fall practically within the age range 550-380 $\mathrm{BC}$ (probabilities $80 \%$ or above). These results indicate that there is a high probability that the real age of these 6 samples is confined into the younger side of the plateau, thus narrowing down the age span to the Archaic/Classical period. In addition, since the differences in the ${ }^{14} \mathrm{C}$ age between the above 6 samples in this group are within the measurement error, we can consider them as belonging to the same period and thus take the average value. This produces a pooled mean value of $2387 \pm 16$ BP (Table 1), and if we calibrate this, we obtain 505-400 BC $(1 \sigma, 68.3 \%)$ and 515-400 BC (2 $\sigma$, 95.4\%) (Figure 10, Table 1). This result strongly indicates that major construction works, as witnessed by the number of samples, occurred during this period. This period would cover the cultural phases of the Late Archaic (500-480 BC) and Classical period (480-323 BC). Further analysis of the probabilities for the average value within the 2- $\sigma$ period shows 515-430 BC $(60.5 \%)$ and $430-400$ (39.5\%), which unfortunately offers no further help in distinguishing between the 2 cultural phases. However, one may observe that within the overall 2- $\sigma$ age range of 515-400 BC, the Classical period is represented by $80 \mathrm{yr}$ and the Late Archaic period by only $35 \mathrm{yr}$. Thus, although not constituting hard evidence, one could tentatively suggest that these 6 posts were cut and used during the Classical period (480-323 BC) and that this period was a phase of major work on the bridge.

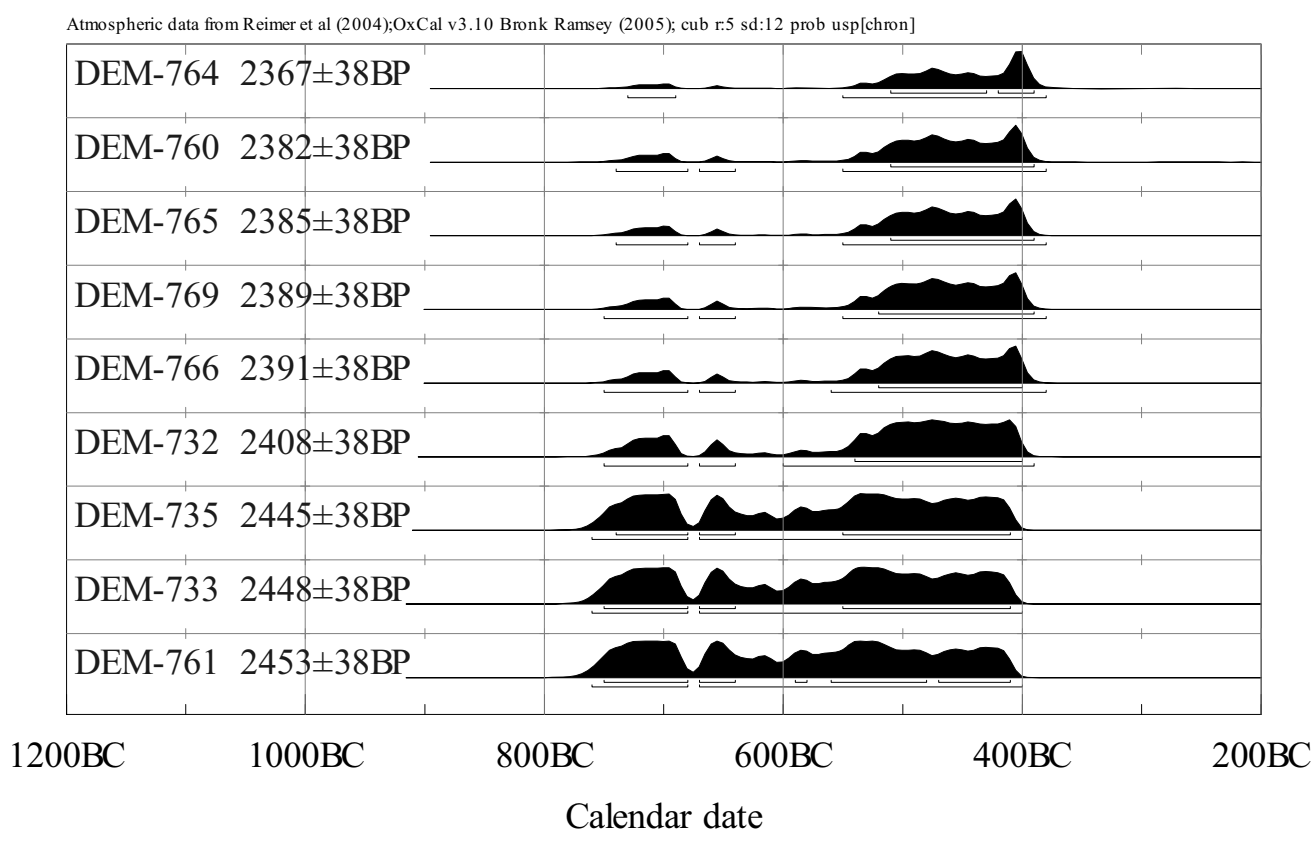

Figure 9 Probability distributions, using OxCal v. 3.10 (Bronk Ramsey 1995, 2001), of the calibrated ages for the samples giving dates within $750-400 \mathrm{BC}$. The samples are plotted according to ${ }^{14} \mathrm{C}$ age.

A separate treatment is perhaps required for the 3 remaining samples (DEM-735, -733, -761), which differ from the rest as their calibrated ages are uniformly distributed under the whole range of the long plateau, even for the 1- $\sigma$ probabilities (Figure 9, Table 1). The probabilities rise at the 2 ends and drop in the middle, but this is naturally due to the shape of the calibration curve. Table 2 lists the details of the probability distributions for these 3 samples and their average value calculated using the CALIB 5.0 program (Stuiver and Reimer 1993; Reimer et al. 2004). It appears that for each sam- 


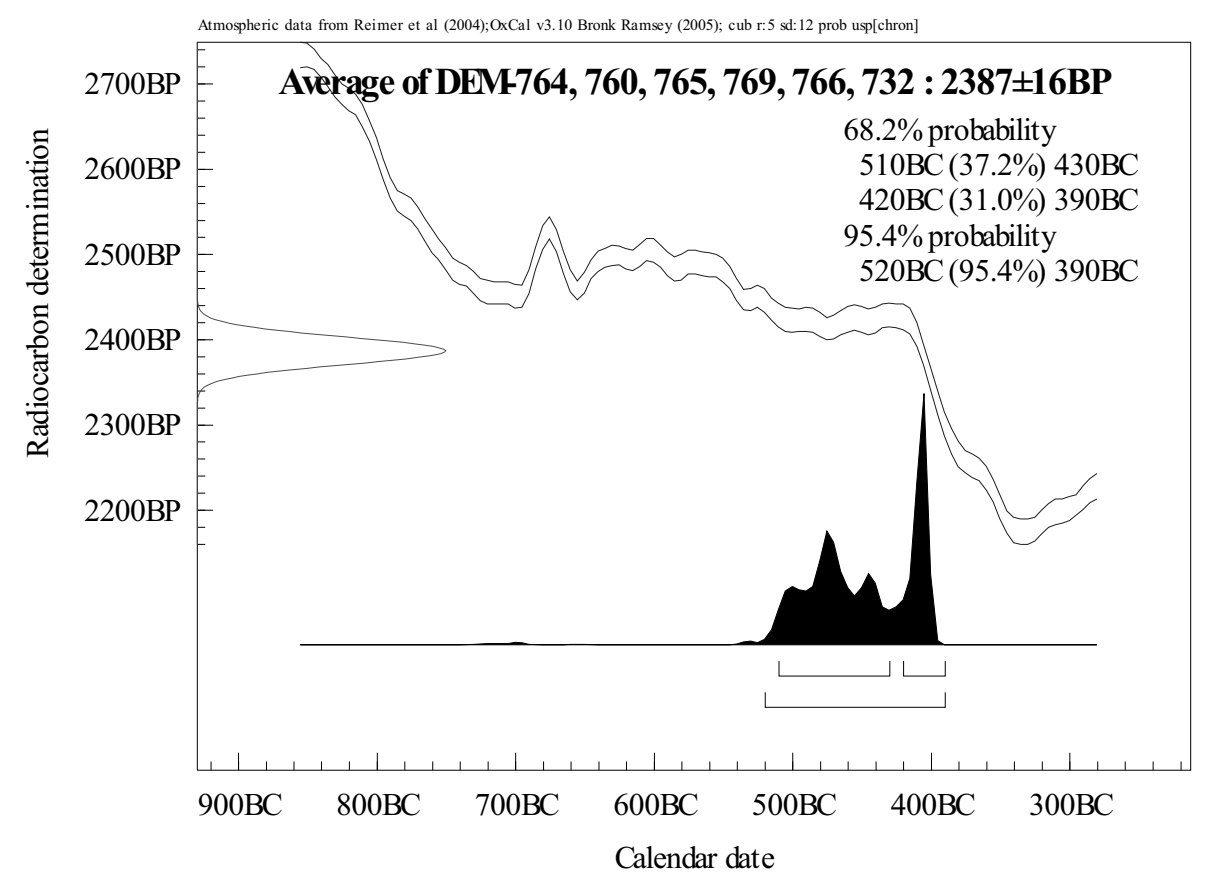

Figure 10 Probability distribution of calibrated dates for the average value of samples DEM-764, -760, $-765,-769,-766,-732$.

ple, the highest probabilities in the 2- $\sigma$ ranges are concentrated in $600-405 \mathrm{BC}(\sim 60 \%)$, and more specifically in 550-410 BC taking into account the 1- $\sigma$ range. This points again to the Archaic/Classical period as the period of first construction time of the bridge. However, the probabilities for an earlier date are not negligible: $38-40 \%$ for $760-600 \mathrm{BC}$ and $25 \%$ for $760-680 \mathrm{BC}$ (Early to Late Iron Age). The difference in ${ }^{14} \mathrm{C}$ age between these samples is negligible and thus we can safely treat them all as representing the same historical event. Their average value is calculated as $2449 \pm 22 \mathrm{BP}$ (Table 1) and, when this is calibrated, shows a high probability of $62.2 \%$ for an age of 595-410 BC, covering the Middle Archaic, the Late Archaic, and the Classical period. Perhaps this age may be confined to 550-415 BC, judging from the $1-\sigma$ probabilities and the plots. Therefore, although the highest probabilities for these 3 older samples are again shifted to the younger side of the plateau spanning over to the Classical period, the Archaic period is now much more represented in the high probability age. Furthermore, there is a lower but not negligible probability for an even earlier date of first construction, stretching to the Late Iron Age: 755-635 BC (38.5\%) or 755-685 BC (28.4\%).

\section{Period II: $\mathbf{3 8 0 - 1 8 0 ~ B C ~}$}

This period is defined by sample DEM-758, belonging archaeologically to the later phases of construction of the bridge. This sample gives calibrated ages of 380-180 BC (2 $\sigma)$ and 355-205 BC $(1 \sigma)$. These dates cover the Late Classical (400-330 BC) and the Hellenistic periods (330-146 BC). Although it is just 1 sample, it suggests that some repairs perhaps took place within one or the other of these periods.

\section{Period III: AD 140-400}

This age range is also defined by 1 sample (DEM-980), which stratigraphically belongs to the surface layers, thought by the excavator to date to Byzantine reconstructions. The calibrated age of this 
Table 2 Probability distribution of calibrated ages for the samples with the older ${ }^{14} \mathrm{C}$ ages (CALIB 5.0, Stuiver and Reimer 1993).

\begin{tabular}{|c|c|c|c|c|}
\hline Lab code no & $\begin{array}{l}\text { Wooden post } \\
\text { number }\end{array}$ & ${ }^{14} \mathrm{C}$ age (BP) & $\begin{array}{l}\text { Calibrated age } \\
\text { ranges (BC) }\end{array}$ & Probability (\%) \\
\hline DEM-735 & 11 & $2445 \pm 38$ & $\begin{array}{l}\frac{1 \text {-sigma }}{740-690} \\
665-645 \\
550-475 \\
475-410 \\
\frac{2-\text { sigma }}{755-685} \\
670-605 \\
600-405\end{array}$ & $\begin{array}{r}25.8 \\
7.1 \\
37.3 \\
29.8 \\
\\
23.7 \\
14.1 \\
62.2\end{array}$ \\
\hline DEM-733 & 374 & $2448 \pm 38$ & $\begin{array}{l}\frac{1 \text {-sigma }}{745-685} \\
665-645 \\
550-475 \\
470-410 \\
\frac{2 \text {-sigma }}{755-680} \\
670-605 \\
600-405\end{array}$ & $\begin{array}{r}28.9 \\
8.6 \\
36.0 \\
26.5 \\
\\
24.1 \\
15.2 \\
60.7\end{array}$ \\
\hline DEM-761 & 73 & $2453 \pm 38$ & $\begin{array}{l}\frac{1 \text {-sigma }}{750-685} \\
665-645 \\
590-580 \\
555-480 \\
470-415 \\
\frac{2 \text {-sigma }}{760-680} \\
670-605 \\
605-410\end{array}$ & $\begin{array}{r}31.0 \\
10.1 \\
2.9 \\
34.3 \\
21.7 \\
\\
24.9 \\
16.7 \\
58.4\end{array}$ \\
\hline $\begin{array}{l}\text { Average for } \\
D E M-735 \\
733,761\end{array}$ & $11,374,73$ & $2449 \pm 22$ & $\begin{array}{l}\frac{1-\text { sigma }}{740-690} \\
665-645 \\
550-485 \\
465-445 \\
445-415 \\
\frac{2-\text { sigma }}{755-685} \\
670-635 \\
620-615 \\
595-410\end{array}$ & $\begin{array}{r}33.4 \\
9.0 \\
38.1 \\
6.6 \\
12.8 \\
\\
\\
28.4 \\
9.1 \\
0.3 \\
62.2 \\
\end{array}$ \\
\hline
\end{tabular}

sample is $140-400 \mathrm{BC}(95.4 \%)$ and $235-340 \mathrm{BC}(68.3 \%)$. This age range is well within the Roman period in Greece during which it is thought that the bridge underwent reconstructions. However, the fact that there is only 1 sample in this age range, albeit perhaps a result of random sampling, indicates that there is no major reconstruction of the bridge during the Roman period. This may be 
explained by the hypothesis that the bridge of the Classical/Hellenistic period survived in good shape and needed only minor repairs during the Roman period.

\section{Period IV: AD 400-580}

This age range is defined by 3 samples (DEM-734, -979, -981). One of these samples comes from a post belonging archaeologically to later phases (later than 5th century BC) and 2 samples come from the surface layers removed and thought to belong to the Byzantine period. The ages of all these samples fall in the Early Christian or Byzantine periods. Their ${ }^{14} \mathrm{C}$ dates are close, so we can take the average value (calibrated age of AD 420-540, $2 \sigma$ ) (Table 1), well within the Early Christian period (4th-6th centuries AD). The 3 random samples dated in this period suggest that during this period, some more systematic reconstruction of the bridge took place.

\section{Period V: AD 440-655}

There are 2 samples defining this age range (DEM-763, -759). The posts from which the samples come are placed close to the foundations of the gate (Figure 4). Archaeologically, these posts are considered to belong to the later phases (later than 5th century BC). They give calibrated ages that greatly overlap, yet DEM-759, being some 30 yr BP older than DEM-763, gives an extended calibration age with a lower edge at AD 440 instead of AD 545 for DEM-763 (Table 1). Both samples fall in the Early Christian to the beginning of the Byzantine period and their mean value (1468 \pm 27 BP) gives a calibrated age of AD 550-645 (2 $\sigma)$. It therefore appears, in conjunction also with the previous 3 samples, that during the Early Byzantine period, continuous reconstruction of the bridge took place. Reconstruction during the Byzantine period was already suggested by the excavator, with no possibility for a better definition of the exact date. The ${ }^{14} \mathrm{C}$ dates allowed a more precise attribution of this reconstruction to the Early Christian to beginning of the Byzantine period.

\section{Period VI: AD 1450-1640}

One sample found in the surface layers and removed during the excavation gave an overall age range of AD 1450-1640 $(2 \sigma)$. Closer inspection of the probability distribution within this range reveals that, due to the intense wiggle in the calibration curve, this can be divided into 2 periods each representing 50\% probability: AD 1450-1535 and 1540-1640. Both periods date after the fall of Constantinople (AD 1453), signifying the end of the Byzantine Empire. They date within the Early Ottoman period for which there is no other literary information about the existence or use of the bridge.

\section{FURTHER DISCUSSION}

\section{Period I, the Earliest Possible Phase}

Starting with the earliest possible period for first construction of the bridge, represented by 3 samples (DEM-761, -733, -735), the archaeological data do not rule out the existence of a bridge on the Strymon River in the last phase of the Early Iron Age, i.e. before the arrival of the first Greek colonists to the mouth of the river. The people of the Early Iron Age settlement of Hill 133 (Lazaridis 1977a; Koukouli-Chryssanthaki 1993) could have constructed a bridge on the narrower passage of the nearby river, a bridge that was destined to be used from the Ancient to the Byzantine and Modern times. Although we do not know yet of any bridges in the area dating to the Early Iron Age, it does not necessarily mean that they never existed in that area. The wooden post technique as a construction method constitutes one mankind's first technological achievements since the beginning of the Neolithic period. The construction of bridges is known from the Prehistoric period (Bougia 1996), 
while in historical times, the occurrence of lakeside post-holed settlements by the Strymon River are mentioned (Herodotus V.16). However, the combination of literary sources together with archaeological finds strongly supports the later chronology, that of the Archaic period, for the first construction of the bridge. The existence of at least 1 bridge was necessary for the function of roads connecting the coast to the mainland. The occurrence of these roads is strongly suggested by the toponym Ennea Odoi, meaning "Nine Roads" (cf. Introduction). Thus, the wooden remains dated to the beginning of the 5th century $\mathrm{BC}$ can be related to Ennea Odoi and to the bridge(s) mentioned by Herodotus.

It is worth noting that 2 out of the 3 samples that belong to this first group (DEM-735, -761) come from posts assumed by the excavator to belong to the oldest phase of the bridge prior to the construction of gate $\Gamma$. The third sample (DEM-733) comes from a group of posts dated conventionally to a later phase, since their top edge stands at a slightly higher level. The lowest edge of this particular post (DEM-733), however, reaches a deeper level and thus it provides one of the oldest dates.

\section{Period I, the Later Phase}

Five out of 6 samples in this group come from posts dated by the excavator to the Classical phase of the bridge. Sample DEM-732 comes from a post located close to the bank of the river (Figure 4), on the extension of rows of posts belonging to the Classical bridge. This fact would further suggest that more posts might be added in the total of 100 considered to belong to the "Classical phase" of the bridge according to Lazaridis.

There is no doubt that the period 540-380 BC, well represented by many ${ }^{14} \mathrm{C}$ samples, was a time of major construction of the bridge. Within this period, however, there could be various phases of reconstruction or expansion of the bridge. The dating of this group of samples is consistent with the bridge of Classical times, mentioned by Thucydides in his description of the occupation of Amphipolis by the Spartan General Brasidas in 424 BC (Thucydides IV.103-108, Diodorus Siculus 12.68). By that time, according to the historian's description, the bridge was not yet connected with the city fortifications. Instead, it was guarded by a small guard caught by surprise by Brasidas, who descended from Kerdyllion Mountain and entered the city (Thucydides IV.103). Thucydides mentions also that $2 \mathrm{yr}$ later, in $422 \mathrm{BC}$ (during the Battle of Amphipolis), the bridge was already connected to the walls by an extension of the fortification to the area of the bridge (Thucydides V.10.6). Gate $\Gamma$ thus had been built in order to adjust the city walls to the already existent bridge. Furthermore, it is highly probable that, during the extension of the city walls, they undertook repair of the bridge as well.

It is not certain if this is the wooden bridge describing the Strymon River as "fair bridged" given by

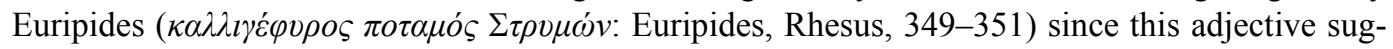
gests a permanent and monumental construction (perhaps of stone). However, although there are scholars who attribute this adjective generally to the Strymon River for its various bridges at different sites (Bakalakis 1970), it seems improbable for the Athenians at the end of the 5th century BC to hear this adjective of the Strymon without relating it with a bridge near their precious colony, Amphipolis. Although some scholars believe that 1 monumental stone bridge existed further to the south, at the area of the Lion monument, the only evidence available to us are these wooden remains to the north, which support the existence of a wooden bridge dated to the end of the 5th century BC, with ${ }^{14} \mathrm{C}$ dates corroborating the interpretation of the archaeological data. For the moment, we cannot be conclusive on the question of if this bridge was wooden in total, or if what Lazaridis found on the marshy area of the eastern bank of the river was part of a wooden substructure for a bridge 
made of stone, as Bougia (1996) suggested, comparing it to the foundation of the Via Appia bridge as well as of other Roman bridges.

\section{Period II, Late Classical-Hellenistic}

Sample DEM-758, attributed to the Late Classical/Hellenistic periods, comes from a large group of posts located on the upper level of the excavation, thus anchoring this group to this chronological phase. The Late Classical and Hellenistic times were also periods of prosperity for Amphipolis. According to literary and archaeological evidence, Amphipolis expanded its control to a broader area to the northwest of the ancient city, namely west of the Strymon at the expense of the neighboring city of Argilos (Hammond and Griffith 1979:119; Hatzopoulos 1998). At the site of Kastrolakkas, located approximately $2 \mathrm{~km}$ northwest from the ancient wooden bridge of Amphipolis, an extended Hellenistic cemetery has been partially explored (Samartzidou 1987).

Although there is no historical evidence for the existence of Late Classical-Hellenistic bridges in the Amphipolis area, sample DEM-758 suggests that the same bridge continued to exist and to connect Amphipolis with the bank across the Strymon. The hypothesis that during the Late Classical and Hellenistic period another bridge might have coexisted in the south, near the Lion monument, proposed by several authors (Pelekidis 1920; Roger 1939; Broneer 1941), has not been corroborated yet by archaeological evidence (Bakalakis 1970; Miller and Miller 1972).

\section{Period III, Roman}

Sample DEM-980, dated to the Late Roman period, comes from the surface upper part of the deposits and had been removed during excavation. Its ${ }^{14} \mathrm{C}$ date represents repair activity of the wooden bridge of the northern walls of Amphipolis, most probably in AD 235-340.

An inscription found in the Strymon River, near the Lion monument (Figures 1 and 2), associates the construction of a bridge not with the reign of the Roman Emperor Tiberius, as Keramopoulos (1932, 1934) proposed, but with the reign of the Augustus (Sarikakis 1971). The location of the bridge referred to by this inscription has not been yet established. Some scholars place this bridge near the Lion monument (Roger 1939; Broneer 1941), while Bakalakis (1940) relates the inscription with a wooden bridge "probably to the north."

However, it is difficult to accept that the bridge of gate $\Gamma$ in the north wall of Amphipolis was the main bridge in the area of Amphipolis in the Roman period. Amphipolis, as a prosperous urban and commercial center at the time, needed more than one bridge on the Strymon River to keep its communications active. Its territory extended to the western bank of the river, as milliaria (road-marking stones) of the Via Egnatia found in this area show (Otatzis 1996).

The main bridge in the area of Amphipolis might have been connected with the Via Egnatia (Figure 1, dashed line). To date, we have no firm evidence that the Via Egnatia crossed the city of Amphipolis. However, it is very likely that the Via Egnatia passed the area without entering the city. It followed most probably the modern road Thessaloniki-Drama, crossing the river at the area of the modern bridge, near the Lion monument, passing by Gate $\Delta$ of the south walls, where the honorary monuments of Augustus and Pison were standing (Lazaridis 1982), and joining the ancient route from Eion to Amphipolis (Amoiridou and Malamidou 1998) (see Figure 1, dashed line). The existence of this ancient route and its south-north direction has been traced from the location of the cemetery and its periboloi excavated on both sides of the modern road, which follows the ancient road from Eion to Amphipolis and the mainland (Malama 2000). 
For the time being, however, there is no archaeological evidence for another bridge in the area of the Lion monument. The only certain evidence for a bridge comes, thus, from the ${ }^{14} \mathrm{C}$ date from the north bridge, which proves its existence and its repair in the Late Roman period.

\section{Periods IV and V, Early Christian-Byzantine}

Intense activity of reconstruction or expansion of the wooden bridge is resumed later, as suggested by several samples within the period AD 420-540, which is the calibrated 2- $\sigma$ range of the mean of the 3 samples (DEM-981, -979, -734) and at AD 550-645, the mean calibrated 2- $\sigma$ age of samples DEM-759 and -763 .

Three samples from this group come from posts of the upper levels separated by Lazaridis, while the other 2 were removed during excavation. These series of ${ }^{14} \mathrm{C}$ dates cover the Early Christian period, when Amphipolis continued to be an important city of northern Greece. The ${ }^{14} \mathrm{C}$ dates thus suggest continuity in the use of the bridge, although there is no literature source to confirm this.

\section{Period VI, Early Ottoman}

Finally, at a much later time, 1 sample of a wooden post (calibrated calendar date of AD 1450-1640, $2 \sigma$ ) testifies to repair and continued function of the bridge during the period of Ottoman occupation of Greece.

Archaeological evidence and literary sources for this period are scarce. There is, however, a reference to a large bridge on the Strymon River built by Ibrahim Pasha (Belon 1553). He is probably Ibrahim of Parga, who was the Great Vizier from AD 1523 to 1594 . The first age range given by ${ }^{14} \mathrm{C}$ dating (AD 1450-1535, 50\% probability within overall $2-\sigma$ range) could fit well with this historical event.

\section{Time Gap between Early Christian and Ottoman Period}

It is noteworthy that although no sample was dated to the period between the Early Christian era and the 16th century, there is strong evidence from historical and literary sources that confirms the existence and use of the bridge during those centuries. From the 11th century onwards, the Athos monasteries used to hold large farms and metochia in the area around Amphipolis, which led to particularly significant economic growth. Thus, several sources from Athos make reference to the broader area and the river in particular. The "Typikon of Gregorios Pakourianos" refers to the bridge of Strymon in AD 1083. It is also known that in this period, around the remains of Amphipolis, on the northwest side of the hills, the small village of Marmarion started developing as an intermediate station for travellers crossing the Strymon through "the passage of Marmarion" (Papangelos 1990: 333-51). In AD 1327-1394, there are sporadic references about the passage of Marmarion in the archives of the Monastery of Zografou. Within the deposits that cover the walls in the north section of ancient Amphipolis, excavations have uncovered remains of buildings, which could be identified with this village. In any case, the 2 Byzantine towers of Marmarion and Chandakas (Figure 1), dated to the 14th century AD, were always visible on both sides of the river and formed important landmarks in the topography of the area (Zikos 1998).

Conducting a more extensive sampling from posts of the latest layers may increase the possibility to have more ${ }^{14} \mathrm{C}$ dates covering this apparent time gap. 


\section{The Last Phases, Late Ottoman Period?}

The last phases of bridge life can be found currently solely in the writings of travellers who visited the area in the 19th century. In 1801, Leake passes as a traveller by the area and describes the bridge. He says that the bridge measures a total length of 300 yards $(\sim 200 \mathrm{~m})$; he also provides a rough drawing for its location (Leake 1835:181, 191). Cousinéry (1831:136) refers to 2 bridges built over the Strymon by Ismail Bey of Serres. In 1861, there was no bridge anymore and crossing the river was undertaken by rafts near the area of the 2 towers (Heuzey and Daumet 1876:166). In 1898, only the foundation of the bridge was visible (Chryssochoos 1898), while in 1920 there is a reference to some scarce remains only, close to the village of Neochori (Pelekidis 1920).

\section{SUMMARY}

The various periods of verified activity for construction or maintenance of the bridge are summarized in Table 3 . The mean values of samples with similar ${ }^{14} \mathrm{C}$ ages are given plus that of some single samples.

Table 3 Summary of ${ }^{14} \mathrm{C}$ dates verifying the construction or repair of the bridge.

\begin{tabular}{|c|c|c|c|}
\hline $\begin{array}{l}\text { Calibrated mean } \\
\text { dates }(2 \sigma)\end{array}$ & $\begin{array}{l}\text { Nr of } \\
\text { samples }\end{array}$ & Cultural period & Comments \\
\hline $760-600 \mathrm{BC}$ & 3 & Late Iron Age & Not very probable \\
\hline $595-410 \mathrm{BC}$ & 3 & Archaic/Classical & Archaic, most probable \\
\hline $515-400 \mathrm{BC}$ & 6 & Classical & Very certain, major construction \\
\hline $380-180 \mathrm{BC}$ & 1 & Late Classical/Hellenistic & $\begin{array}{l}\text { Representative of a group of posts in } \\
\text { same period }\end{array}$ \\
\hline AD $140-400$ & 1 & Late Roman & Not much activity \\
\hline AD $420-540$ & 3 & Early Christian/Byzantine & Systematic repair/reconstruction \\
\hline AD 550-645 & 2 & Early Byzantine & Continuous repair/reconstruction \\
\hline AD $1450-1640$ & 1 & Early Ottoman & $\begin{array}{l}\text { Most probably in AD 1450-1535 (Ibra- } \\
\text { him of Parga) }\end{array}$ \\
\hline
\end{tabular}

Thorough integration of the historical and archaeological evidence together with the information offered by ${ }^{14} \mathrm{C}$ dating have enlightened specific periods of works on the bridge and highlighted the fact that the bridge on the Strymon River, discovered near ancient Amphipolis, was functioning for about 2500 yr.

The probable identification of the Archaic phase (Period I) that had not been defined by excavation contributes significantly to the history of the bridge. It demonstrates that the bridge preceded the foundation of Amphipolis by the Athenians. Further on, the numerous ${ }^{14} \mathrm{C}$ dates in the 5 th century $\mathrm{BC}$ reconfirms the chronology suggested by the archaeological data for a large group of wooden posts. They suggest continuous construction activities during the first decades of the foundation of the Athenian colony and are consistent with all the available historical evidence.

In the centuries to follow, throughout the Late Classical, Hellenistic, Roman, and Early Christian periods, we can see successive phases of the bridge involving many subphases of repairs rather than one phase of complete reconstruction.

Thorough and systematic study of the excavation data from the latest layers would shed some more light on the Byzantine phase of this bridge, referred to in the literary sources as the Byzantine period. The ${ }^{14} \mathrm{C}$ dates, however, prove the existence of the wooden bridge during Early Ottoman times. 
The present study, based on the existent archaeological data, can be further advanced with further excavation of the bridge, in parallel with continuation of the ${ }^{14} \mathrm{C}$ analyses during the conservation works. New series of ${ }^{14} \mathrm{C}$ dates on selected samples may offer further possibilities to better define the phases of the building and use of the wooden bridge.

\section{ACKNOWLEDGMENTS}

We are indebted to Dr Bernd Kromer of the Radiocarbon Laboratory in Heidelberg for constant help and advice concerning the gas proportional counters and other laboratory procedures.

\section{REFERENCES}

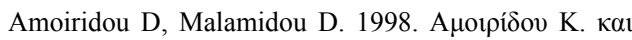

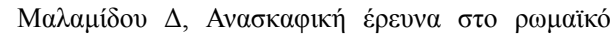

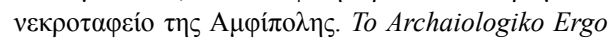
sti Makedonia kai Thraki 12:77-83.

Babelon E. 1967. Traité de monnaies grecques et romaines. Volume II: Description historique. Volume IV: Grèce septentrionale aux Ve et Ive siècles avant J.C. Bologna: Forni.

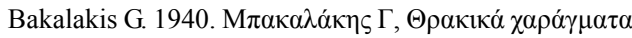

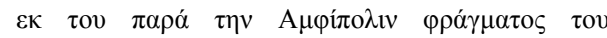

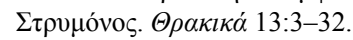

Bakalakis G. 1970. The "Classical" bridge at Amphipolis. American Journal of Archaeology 74(3):289-91.

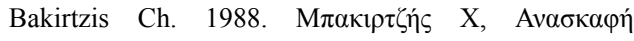

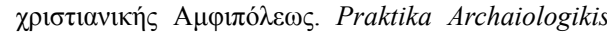
Etaireias Athinon 143:135-42.

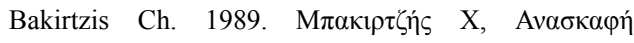

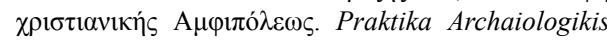
Etaireias Athinon 144:216-21.

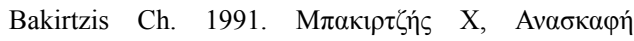

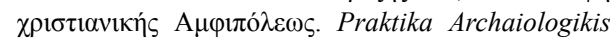
Etaireias Athinon 146:212-91.

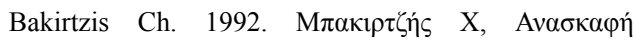

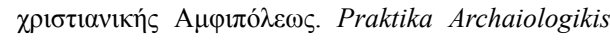
Etaireias Athinon 147:167-75.

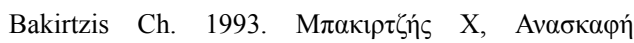

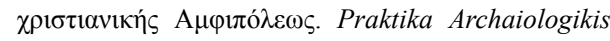
Etaireias Athinon 148:128-34.

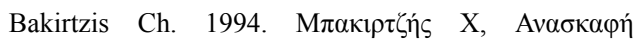

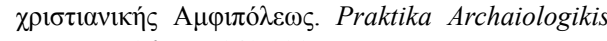
Etaireias Athinon 149:131-7.

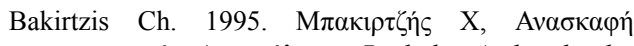

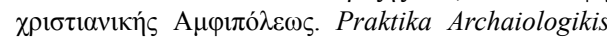
Etaireias Athinon 150:115-25.

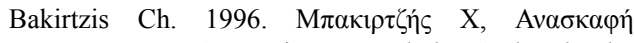

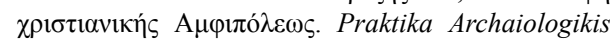
Etaireias Athinon 151:229-41.

Bakirtzis Ch. 2000. The decline and destruction of Early Christian Amphipolis. In: Bartlome N, Fluckiger E, editors. Stadtzerstorrung und Wiederaufbau. Band 2. Bern: Haupt. p 159-67.

Belon P. 1553. Voyage au Levant: Les observations de plusieurs singularités et choses mémorables, trouvées en Grèce, Asie, Judée, Egypte, Arabie et autres pays étranges. Paris.

Bonias Z. 2000. Une inscription de l'ancienne Verge. Bulletin de Correspondance Hellénique 124:227-46.

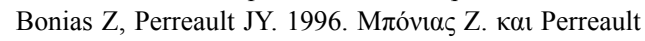

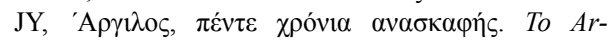
chaiologiko Ergo sti Makedonia kai Thraki 10:67380.

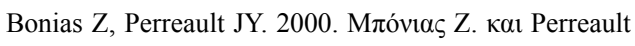

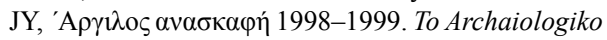
Ergo sti Makedonia kai Thraki 14:109-15.

Bougia P. 1996. Ancient bridges in Greece and coastal Asia Minor [PhD dissertation]. Philadelphia: University of Pensylvania.

Broneer O. 1941. The Lion Monument at Amphipolis. Cambridge: Harvard University Press. 76 p.

Bronk Ramsey C. 1995. Radiocarbon calibration and analysis of stratigraphy: the OxCal program. Radiocarbon 37(2):425-30.

Bronk Ramsey C. 2001. Development of the radiocarbon program. Radiocarbon 43(2A):355-63.

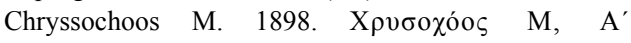

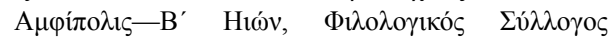

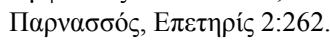

Cousinéry EM. 1831. Voyage dans la Macédoine. Volume 1. Paris: Impr. Royale.

de Vries H, Barendsen GW. 1953. Radiocarbon dating by a proportional counter filled with carbon dioxide. Physica 19:987-1003.

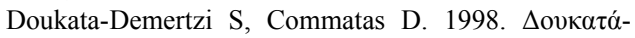

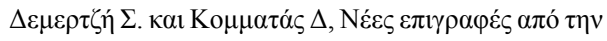

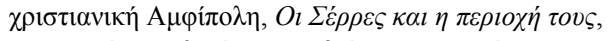

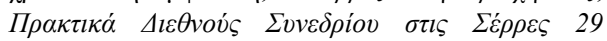

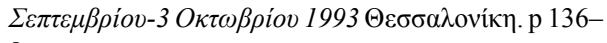
8.

Duhn A. 1981. The survey of Chryssoupolis and Byzantine fortifications of the lower Strymon Valley. In: $X V I$ Internationaler Byzantinistenkongress Akten II/4: 605-14.

Duhn A. 1990. Byzantine topography of southeastern

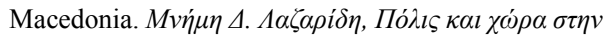

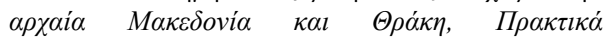

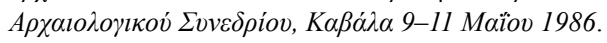
Recherches Francohelléniques I. Thessaloniki. p 30631.

Gomme AW. 1956. An Historical Commentary on Thucydides. Volume 3. 4th edition. Oxford: Oxford 
University Press.

Hammond N, Griffith GT. 1979. A History of Macedonia. Volume II: 550-336 BC. Oxford: Oxford University Press.

Hatzopoulos M. 1998. Macedonian Institutions under the Kings. Athens: Kentro Ellinikis kai Romaikis Archaiotitas.

Heuzey L, Daumet H. 1876. Mission archéologique de Macédoine. Paris: Librairie Firmin Didot. p 165-72.

Jones N. 1977. The topography and strategy of the Battle of Amphipolis in 422. California Studies in Classical Antiquity 10:72-6.

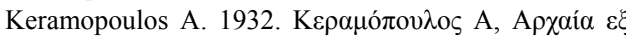
А

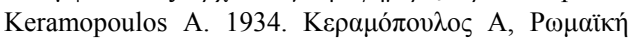

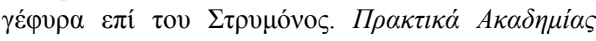

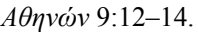

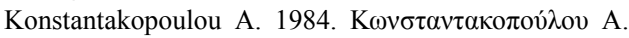

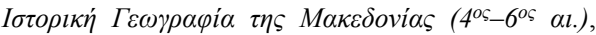
Iڤóvviva.

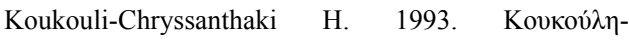

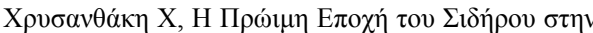

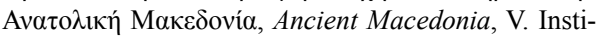
tute for Balkan Studies, 240, Thessaloniki. p 682-4.

Koukouli-Chryssanthaki H, Samartzidou S, Duhn A, Catling R, Tziavos X, Anagnostou Ch. 1996.

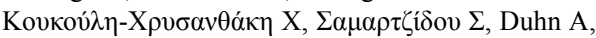

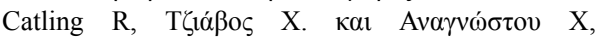

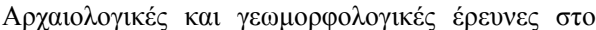

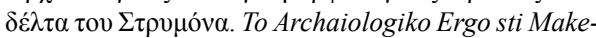
donia kai Thraki 10:673-80.

Kromer B, Münnich KO. 1992. $\mathrm{CO}_{2}$ gas proportional counting in radiocarbon dating - review and perspective. In: Taylor RE, Long A, Kra RS, editors. Radiocarbon After Four Decades: An Interdisciplinary Perspective. New York: Springer-Verlag. p 184-97.

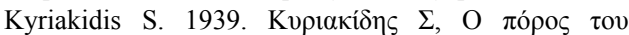

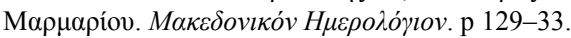

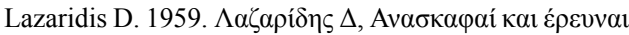

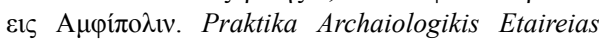
Athinon 114:42-6.

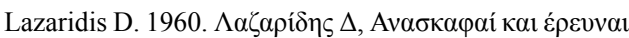

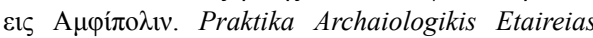
Athinon 115:67-73.

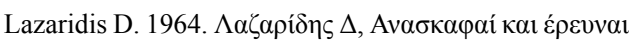

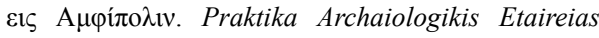
Athinon 119:35-40.

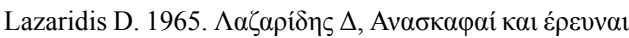

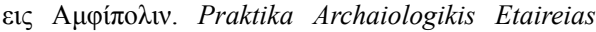
Athinon 120:47-52.

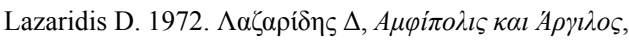

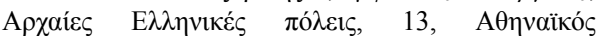

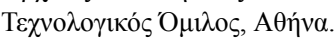

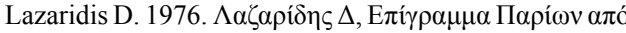

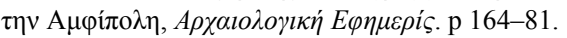

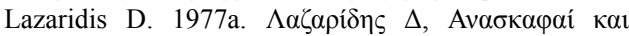

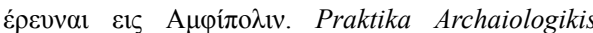

Etaireias Athinon 132(A):39-42

Lazaridis D. 1977b. La cité grecque d'Amphipolis et son système de défense. Comptes Rendus de l'Académie des Inscriptions et Belles Lettres. p 194-214.

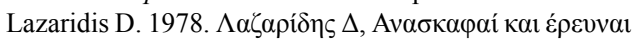

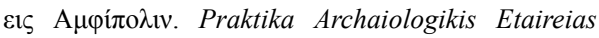
Athinon 133:51-3.

Lazaridis D. 1982. Les fortifications d'Amphipolis. La fortification dans l'histoire du monde grec. In: Colloque international, Valbonne CNRS. p 31-8.

Lazaridis D. 1997. Amphipolis, Guides of the Archaeological Receipts Fund. 2nd edition. Athens: Hellenic Ministry of Culture.

Leake WM. 1835. Travels in Northern Greece. Volume 3. London: J. Rodwell.

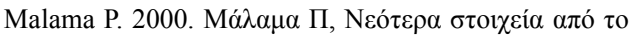

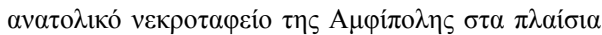

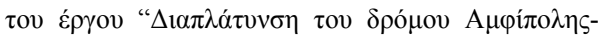

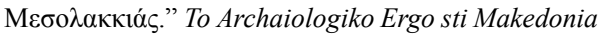
kai Thraki 14:55-70.

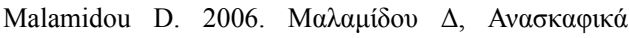

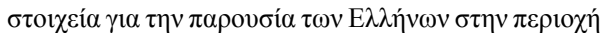

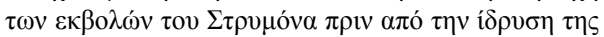

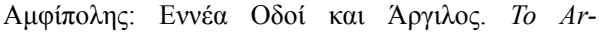
chaiologiko Ergo sti Makedonia kai Thraki 20:18596.

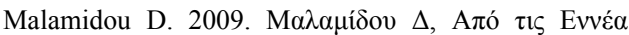

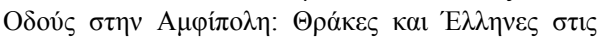

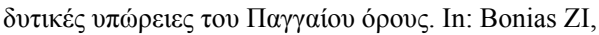
Perreault JY, editors. Greeks and Thracians in Coastal and Inland Thrace During the Years Before and After the Great Colonisation. Proceedings of the International Symposium, Thasos, 26-27 September 2008 Thasos. p 27-36.

Miller S, Miller S. 1972. Architectural blocks from the Strymon. Archaiologikon Deltion 27A:140-69.

Münnich KO. 1957. Messung naturlichen radiokohlenstoffs mit einem $\mathrm{CO}_{2}$ proportional zahlrohr. Einige anwendungen der methode. Inaugural-dissertation zur erlangung der doktorwurde hohen naturwissenschaftlich-mathematischen fakultat der RuprechtKarl-Universitat zu Heidelberg, Germany.

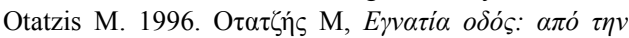

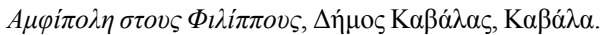

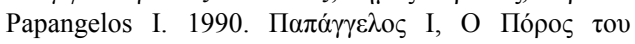

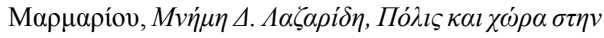

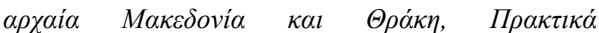

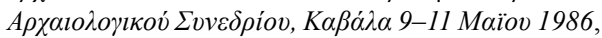
Recherches Francohelléniques, I, Thessaloniki:333351.

Papastavrou I. 1936. Amphipolis, Geschichte und Prosopographie. Leipzig: Dieterich. $152 \mathrm{p}$.

Papazoglou F. 1953. Eion-Amphipoli-Chryssoupoli. Zbornik Radova Vizantoloskog Instituta 2:14-8.

Papazoglou F. 1988. Les Villes de Macédoine à l'époque romaine. Bulletin de Correspondance Hellénique Suppl. p 11. 
Pedley Griffiths J. 1998. Greek Art and Archaeology. London: Prentice Hall.

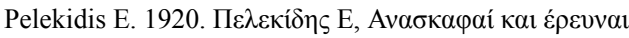

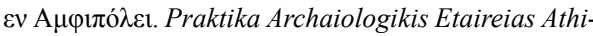
non 75:80-94.

Perreault JY, Bonias Z. 1998. Nouvelles recherches archéologiques sur le site d'Argilos. Ol $\Sigma \dot{\varepsilon} \rho \rho \varepsilon \varsigma \kappa \alpha l \eta$

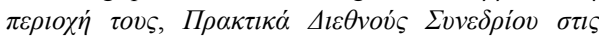

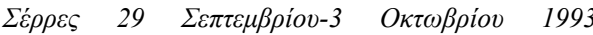

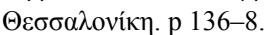

Perdrizet P. 1922. Etudes Amphipolitaines. Bulletin de Correspondance Hellénique 46:40-1.

Polach HA. 1976. Radiocarbon dating as a research tool in archaeology: hopes and limitations. In: Barnard N, editor. Proceedings of the Symposium on Scientific Methods of Research in the Study of Ancient Chinese Bronzes and Southeast Asian Metal and Other Archaeological Artifacts. Australian National University, Dept. Far Eastern History. p 255-98.

Pritchett WK. 1965. Amphipolis. In: Pritchett WK. Studies in Ancient Greek Topography Part I. Berkeley: University of California Press. p 30-45.

Pritchett WK. 1971. The bridge over Strymon: a correction. American Journal of Archaeology 75:92.

Pritchett WK. 1981. Amphipolis restudied. In: Pritchett WK. Studies in Ancient Greek Topography Part III. Berkeley: University of California Press. p 298-346.

Reimer PJ, Baillie MGL, Bard E, Bayliss A, Beck JW, Bertrand CJH, Blackwell PG, Buck CE, Burr GS, Cutler KB, Damon PE, Edwards RL, Fairbanks RG, Friedrich M, Guilderson TP, Hogg AG, Hughen KA, Kromer B, McCormac G, Manning S, Bronk Ramsey C, Reimer RW, Remmele S, Southon JR, Stuiver M, Talamo S, Taylor FW, van der Plicht J, Weyhenmeyer CE. 2004. IntCal04 terrestrial radiocarbon age calibration, 0-26 cal kyr BP. Radiocarbon 46(3):1029-58.

Roger J. 1939. Le monument du lion d'Amphipolis. Bulletin de Correspondance Hellénique 63:8.

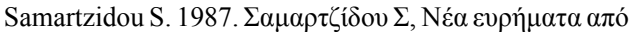

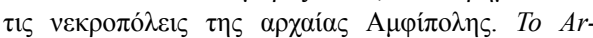
chaiologiko Ergo sti Makedonia kai Thraki 1:327-41.

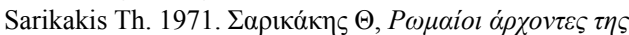

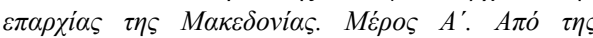

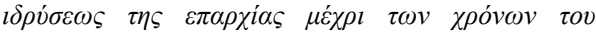

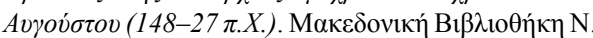

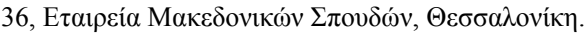

Schoch H, Bruns M, Münnich KO, Münnich M. 1980. A multi-counter system for high precision carbon-14 measurements. Radiocarbon 22(2):442-7.

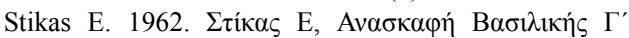

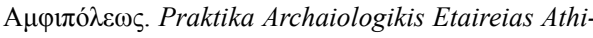
non 117:42-6.

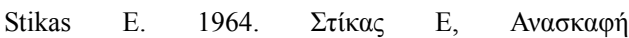

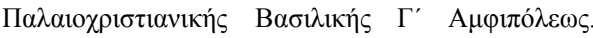
Praktika Archaiologikis Etaireias Athinon 119:41-2.

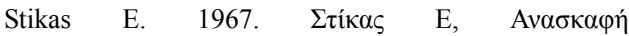

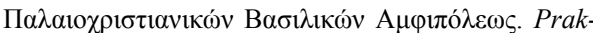

tika Archaiologikis Etaireias Athinon 122:83-8.

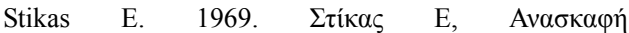

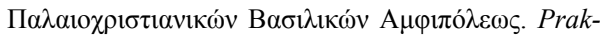
tika Archaiologikis Etaireias Athinon 124:54-8.

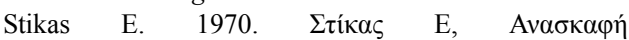

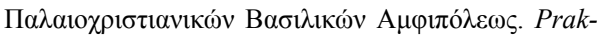
tika Archaiologikis Etaireias Athinon 125:50-4.

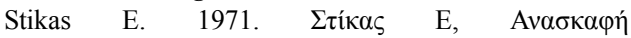

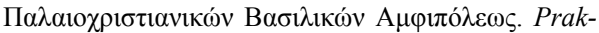
tika Archaiologikis Etaireias Athinon 126:43-9.

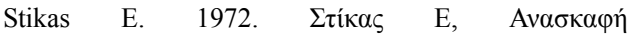

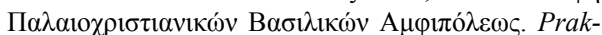
tika Archaiologikis Etaireias Athinon 127:49-62.

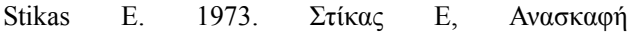

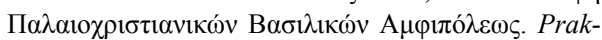
tika Archaiologikis Etaireias Athinon 128:35-42.

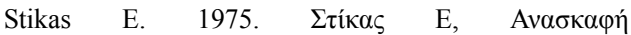

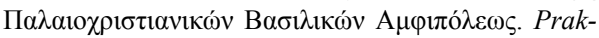
tika Archaiologikis Etaireias Athinon 130:72-9.

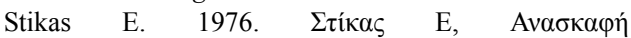

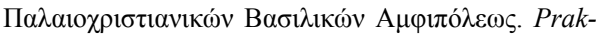
tika Archaiologikis Etaireias Athinon 131:99-110.

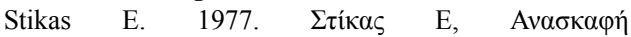

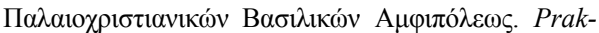
tika Archaiologikis Etaireias Athinon 132(A):46-53.

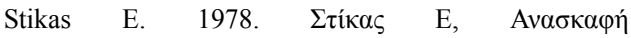

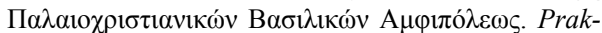
tika Archaiologikis Etaireias Athinon 133:59-63.

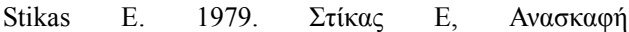

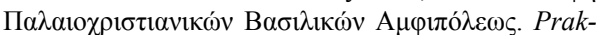
tika Archaiologikis Etaireias Athinon 134:80-9.

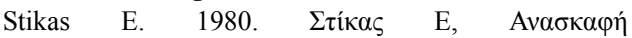

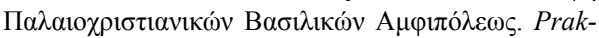
tika Archaiologikis Etaireias Athinon 135:14-20.

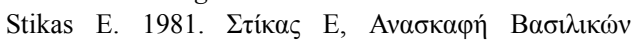

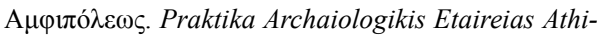
non 136(A):26-32.

Stuiver M, Polach HA. 1977. Discussion: reporting of ${ }^{14} \mathrm{C}$ data. Radiocarbon 19(3):355-63.

Stuiver M, Reimer PJ. 1993. Extended ${ }^{14} \mathrm{C}$ data base and revised CALIB $3.0{ }^{14} \mathrm{C}$ age calibration program. $R a$ diocarbon 35(1):215-30.

Svoronos J. 1919. L'hellénisme primitif de Macédoine prouvé par la numismatique et l'or du Pangée, Ed. Leroux, Paris.

Vanterpool E. 1965. Amphipolis, Hill 133. In: Pritchett WK. Studies in Ancient Greek Topography Part I. Berkeley: University of California Press. p 46-8.

Zikos N. 1989. Amphipolis, Early Christian and Byzantine Amphipolis. Guides of the Archaeological Receipts Fund. Athens: Hellenic Ministry of Culture.

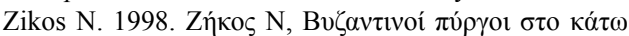

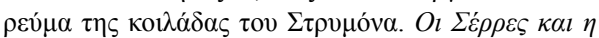

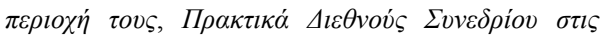

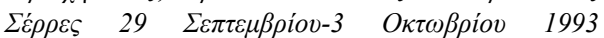
$\Theta \varepsilon \sigma \sigma \alpha \lambda$ ovík». p 312-7. 